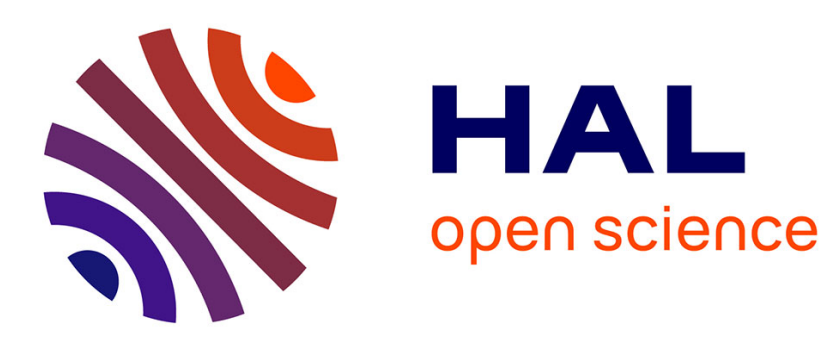

\title{
Does income polarization affect economic growth? The case of the European regions
}

Roberto Ezcurra

\section{To cite this version:}

Roberto Ezcurra. Does income polarization affect economic growth? The case of the European regions. Regional Studies, 2009, 43 (02), pp.267-285. 10.1080/00343400701808899 . hal-00516184

\section{HAL Id: hal-00516184 \\ https://hal.science/hal-00516184}

Submitted on 9 Sep 2010

HAL is a multi-disciplinary open access archive for the deposit and dissemination of scientific research documents, whether they are published or not. The documents may come from teaching and research institutions in France or abroad, or from public or private research centers.
L'archive ouverte pluridisciplinaire HAL, est destinée au dépôt et à la diffusion de documents scientifiques de niveau recherche, publiés ou non, émanant des établissements d'enseignement et de recherche français ou étrangers, des laboratoires publics ou privés. 


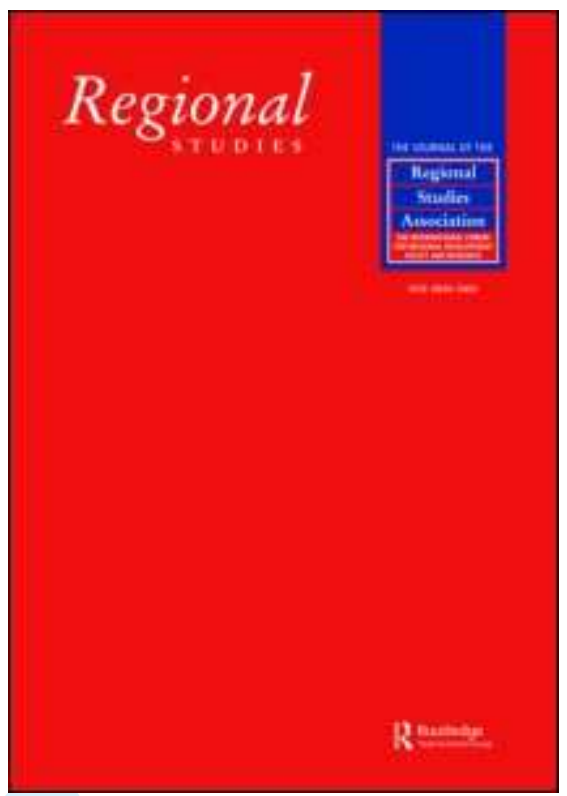

\section{Does income polarization affect economic growth? The case of the European regions}

\begin{tabular}{|r|l|}
\hline Journal: & Regional Studies \\
\hline Manuscript ID: & CRES-2006-0280.R1 \\
\hline Manuscript Type: & Main Section \\
\hline JEL codes: & $\begin{array}{l}\text { D30 - General < D3 - Distribution < D - Microeconomics, R11 - } \\
\text { Regional Economic Activity: Growth, Development, and Changes < } \\
\text { Economics }\end{array}$ \\
\hline Keywords: & \begin{tabular}{l} 
Income polarization, Economic growth, Regions, European Union \\
\hline
\end{tabular} \\
\hline
\end{tabular}

\section{SCHOLARONE"}

Manuscripts 


\title{
Does income polarization affect economic growth?
}

\section{The case of the European regions}

\author{
Roberto Ezcurra* \\ Department of Economics \\ Universidad de Castilla-La Mancha
}

Final version: June 2007

\section{¿Afecta la polarización de la renta al crecimiento económico? \\ El caso de las regiones europeas}

\author{
Roberto Ezcurra ${ }^{\dagger}$ \\ Department of Economics \\ Universidad de Castilla-La Mancha \\ First: November 06. Accepted: June 07
}

\begin{abstract}
(panish)
Este trabajo examina la relación entre la polarización de la renta y el crecimiento económico en las regiones de la Unión Europea a lo largo del período 1993-2003. El

\footnotetext{
* Postal address: Departament of Economics, Universidad de Castilla-La Mancha, Ronda de Toledo s/n. 13071 Ciudad Real (Spain). E-mail: Roberto.Ezcurra@uclm.es.

${ }^{\dagger}$ Postal address: Departament of Economics, Universidad de Castilla-La Mancha, Ronda de Toledo s/n. 13071 Ciudad Real (Spain). E-mail: Roberto.Ezcurra@uclm.es.
} 
análisis llevado a cabo indica que el nivel de polarización de la renta influye negativamente en el crecimiento regional. De hecho, este resultado es robusto a distintas especificaciones alternativas que incluyen variables explicativas adicionales como el nivel inicial de PIB por habitante, la estructura sectorial, el stock de capital humano, la densidad de población o el potencial de mercado. Asimismo, cabe señalar que la correlación negativa observada no depende del número de grupos utilizado para analizar el grado de polarización de la renta en las regiones consideradas.

Key words: Polarización de la renta, crecimiento económico, regiones, Unión Europea.

\section{La polarisation des revenus affecte t'elle la croissance économique?}

\section{$\underline{\text { Le cas des régions européennes }}$}

\section{$\underline{\text { Roberto Ezcurra }}$}

\section{Résumé}

Cet article étudie les relations entre la polarisation des revenus et la croissance économique dans les régions de l'Union Européenne entre 1993 et 2003. Les résultats indiquent que le niveau de la polarisation des revenus est associé de manière négative au développement régional. Ce résultat conforte en fait diverses autres spécifications y compris un certain nombre de variables explicatives additionnelles comme le PIB par habitant, le mix industriel, le capital humain, la densité de population ou le potentiel des marchés. En outre, il convient de noter que la corrélation négative observée entre la polarisation et les résultats économiques ne dépend pas du nombre de groupes utilisés 
pour analyser le degré de stratification des revenus dans les régions échantillons.

\author{
Mots-clés : polarisation des revenus, croissance économique, régions, Union \\ Européenne.
}

Classification JEL: D30, R11.

Wirkt sich eine Einkommenspolarisierung auf das Wirtschaftswachstum aus? Der Fall der europäischen Regionen

Roberto Ezcurra

\begin{abstract}
In diesem Artikel wird die Beziehung zwischen der Einkommenspolarisierung und dem Wirtschaftswachstum in den Regionen der Europäischen Union im Zeitraum von 1993 bis 2003 beschrieben. Die Ergebnisse weisen darauf hin, dass das Ausmaß der Einkommenspolarisierung in einer negativen Verbindung zum Regionalwachstum steht. Dieses Ergebnis ist darüber hinaus auch bei Verwendung von verschiedenen alternativen Spezifikationen robust, darunter eine Reihe zusätzlicher erklärender Variablen wie z. B. das anfängliche ProKopf-Bruttoinlandsprodukt, der Branchenmix, das Humankapital, die Bevölkerungsdichte oder das Marktpotenzial. Darüber hinaus sollte beachtet werden, dass die beobachtete negative Korrelation zwischen der Polarisierung und der Wirtschaftsleistung nicht von der Anzahl der Gruppen abhängt, die zur Analyse des Ausmaßes der Einkommensstratifizierung innerhalb der untersuchten Regionen herangezogen werden.
\end{abstract}

Key words:

Einkommenspolarisierung

Wirtschaftswachstum

Regionen

Europäische Union

JEL classification: D30, R11.

\begin{abstract}
This article examines the relationship between income polarization and economic
\end{abstract}


growth in the regions of the European Union over the period 1993-2003. The results indicate that the level of income polarization is negatively associated with regional growth. This finding is in fact robust to various alternative specifications including a number of additional explanatory variables, such as initial per capita GDP, industry mix, human capital stock, population density or market potential. Furthermore, it should be noted that the observed negative correlation between polarization and economic performance does not depend on the number of groups used to analyse the degree of income stratification within the sample regions.

Key words: Income polarization, economic growth, regions, European Union. JEL classification: D30, R11.

\section{Introduction}

Over the last fifteen years there have been numerous studies on spatial disparities in the European Union (EU) using a variety of different approaches (see ECKEY and TÜRK (2006) for a recent review of this literature). Various reasons contribute to explain the interest surrounding this issue. Among them, it is worth mentioning the major advances made over the last two decades in economic growth theory, coinciding with the introduction of endogenous growth models in the mid 1980s. The assumptions underlying these models ultimately allow for the reversal of the neoclassical prediction of convergence, and lead to the conclusion that the faster growth of rich economies causes territorial imbalances to increase over time (BARRO and SALA-I-MARTIN, 1995). In fact, the self-sustained and spatially selective nature of economic growth has been stressed by the models of the "new economic geography" (OTTAVIANO and 
PUGA, 1998). According to these theories, increasing returns and agglomeration economies would explain the accumulation of activity and income in the more dynamic areas, which would lead in the final instance to spatial divergence. Academic debate aside, however, the increasing relevance of this topic in the EU has much to do with the strong emphasis placed on achieving economic and social cohesion in the context of the current economic integration process, especially since the signing of the Single Act and the Maastricht agreements. This directly raises the need to reduce the differences in terms of development across the European regions (EUROPEAN COMMISSION, 2004).

The literature on spatial disparities within the EU has highlighted the impact of various factors on regional growth. They include the sectoral composition of economic activity (NEVEN AND GOUYETTE, 1995), structural change processes (PACI, 1997), infrastructure endowment (GIL et al., 2002), human capital stock (RODRÍGUEZ-POSE and VILALTA-BUFI, 2005), technology and innovation capacity (BILBAO-OSORIO and RODRÍGUEZ-POSE, 2004), spatial externalities (LÓPEZ-BAZO et al., 2004), European regional policy (RODRÍGUEZ-POSE and FRATESI, 2004a), market potential (BRÜLHART et al., 2004) or social capital (BEUGELSDIJK and VAN SCHAIK, 2005). However, the possible influence of personal income distribution on economic performance in the EU has received hardly any attention in the literature. In fact, to the best of our knowledge, the only exception in this respect is the work of MARTINO and PERUGINI (2006), who analyse the relationship between income inequality and economic growth in the EU regions. Following this line of research, this article examines the role played by income polarization in explaining regional growth processes in the EU. To investigate this issue, we have estimated the level of income polarization registered by the European regions, which provides relevant information 
when it comes to assessing the degree of social cohesion in the EU. In this respect, it is worth mentioning that the ultimate aim of this research is to achieve a deeper understanding of the nature of the observed spatial disparities in the European setting, in order to draw some useful implications for EU regional policy design.

Before going any further, a word of warning is necessary to alert readers about the conceptual differences that exist between the notion of polarization and that of inequality. In relation to this, JENKINS (1996, p.34) points out that "polarization provides a challenge for our thinking about how we assess income distributions, since the measurement tools economists have developed focus almost exclusively on changes in income levels and dispersion.” In particular, it is important to emphasize that, unlike polarization measures, the conventional indices of inequality commonly employed in the literature are of no use when distinguishing whether the population is clustered around the average of the distribution or around two or more separate poles (ESTEBAN and RAY, 1994; WOLFSON, 1994). Accordingly, inequality and polarization capture different features of the distribution object of analysis, and can move in opposite directions. For an illustration of this idea, we can consider the following example (ANDERSON, 2004). Let us assume that the distribution under study, $f$, can be expressed as an equally weighted mixture of normals $N\left(\mu_{i}, \sigma_{i}^{2}\right)$, with $i=1,2$. This means that $\sigma_{f}^{2}=0.5\left(\sigma_{1}^{2}+\sigma_{2}^{2}+\left(\mu_{1}-\mu_{2}\right)^{2}\right)$. In this situation, increased polarization, interpreted as any combination of reductions in sub-population variances and increased distance between sub-population averages, can be seen either to increase, leave unchanged, or decrease inequality, as measured by the variance of $f$. This example shows clearly that inequality and polarization are two different concepts that should be examined separately when analysing income distributions.

Previous studies on the link between income distribution and economic performance 
have focused mainly on the role played by income inequality (e.g. ALESINA and RODRIK, 1994; PERSON and TABELLINI, 1994; BENABOU, 1996; LI and ZOU, 1998; FORBES, 2000; MARTINO and PERUGINI, 2006), thus ignoring the possible influence in this context of the degree of income stratification in the economies under consideration. Nevertheless, it needs to be said that there are various theoretical arguments that suggest the potential relevance of polarization in this framework. Thus, as pointed out by ESTEBAN and RAY (1994), income polarization gives rise to the generation of social tensions. This is especially important, since several studies have stressed the negative impact of social unrest on economic performance (e.g. VENIERIS and GUPTA, 1986; BENHABIB and RUSTICHINI, 1996). Furthermore, polarization processes are characterized by the diminution of the middle class in income distributions (e.g. HORRIGAN and HAUGEN, 1988; BEACH et al., 1998). This may have a negative impact on economic growth, since middle class consensus promotes economic development by supporting political stability, enhancing public service endowment and improving access to education (EASTERLY, 2001a,b). These arguments highlight the need to tackle empirically the analysis of the relationship between income polarization and economic growth, as has been done in this article.

We were able to undertake our study thanks to the use of the European Community Household Panel (ECHP). The ECHP, which was constructed under Eurostat coordination, is the only homogeneous survey of its kind covering the $15 \mathrm{EU}$ member states prior to the 2004 and 2007 enlargements, and with the capacity to supply regionally disaggregated data on personal income distribution (EUROSTAT, 1996). The analysis performed in this paper is based on this source and covers 61 NUTS-1 regions in eight EU countries during the period $1993-2003^{\mathrm{i}}$. It is important to note in this respect that the level of territorial disaggregation and time frame considered in the article are 
decisively conditioned by the availability of data from the ECHP, a point that should be taken into consideration when assessing the results obtained in the empirical analysis ${ }^{\mathrm{ii}}$. The rest of the article is structured as follows. The next section presents an overview of the main theoretical arguments that can be used to justify the possible influence of income polarization on economic growth. After establishing the theoretical framework in which to fit our study, Section 3 examines the growth patterns of the EU regions during the sample period, and provides evidence on their degree of income polarization. Section 4 employs various alternative specifications of a reduced-form growth model to analyse the impact of income polarization on economic growth in the EU regions, paying particular attention to the robustness of the results obtained. Finally, section 5 draws the main conclusions and the policy implications of the research.

\section{Income polarization and economic growth: Theoretical and empirical background}

The theoretical literature on the relationship between income distribution and macroeconomic performance has expanded enormously in recent years, coinciding with the resurgence of interest in the determinants of economic growth at the beginning of the 1990s (AGHION et al., 1999; EICHER and TURNOVSKY, 2003). The underlying theory of this line of research is that income distribution can affect investment levels in physical and human capital, which in turn determinates the growth rate of the economy. Within this framework, a great number of authors have investigated the impact of income inequality on economic growth through different mechanisms that often work in opposite directions (e.g. PEROTTI, 1996; BARRO, 2000). Empirical research is therefore key to understanding the nature of this relationship. Thus, the last decade has seen the publication of various works that examine this issue using country data. Studies 
based on cross-sectional approaches report a negative correlation between income inequality and economic growth (ALESINA and RODRIK, 1994; PERSSON and TABELLINI, 1994; CLARKE, 1995; BENABOU, 1996), which represents a challenge for the traditional equity/growth trade-off. Nevertheless, other researchers have found a positive relationship using panel data models (LI and ZOU, 1998; FORBES, 2000). It should be noted, however, that all these studies are based on different international databases compiled from information on income distribution in various countries. As a consequence, the authors themselves acknowledge that the data employed lacks homogeneity, which inevitably casts some doubt on the robustness of the results obtained (BENABOU, 1996; ATKINSON and BRANDOLINI, 2001). A possible solution to these problems can be found in the use of regional data. Following this strategy, a small number of works have examined the relationship between income inequality and economic growth with data from the US states (PARTRIDGE, 1997, 2005; PANIZZA, 2002) or the European regions (MARTINO and PERUGINI, 2006). Nevertheless, the findings of these contributions are not conclusive. In this respect, PANIZZA (2002) has highlighted that specification changes and slight differences in the method used to measure income inequality may affect the results of the econometric analysis.

In any event, these studies do not take into account that there are various aspects of the income distribution that cannot be captured by the conventional inequality indices employed in the econometric analyses carried out. Specifically, these measures do not help in distinguishing whether the population is clustered around the average or around two or more separate poles (LEVY and MURNANE, 1992; WOLFSON, 1994), which impedes to quantify with accuracy the level of polarization of the distribution under consideration. Nevertheless, as we will show later, there are several theoretical 
arguments suggesting that polarization may, in some cases, be more relevant than inequality for economic growth. This is because inequality, unlike polarization, does not properly capture the degree of social tension associated with a specific distribution (ESTEBAN and RAY, 1994). For a better understanding of this idea, let us consider an income distribution divided into two well defined groups characterized by substantial intra-group homogeneity and inter-group heterogeneity. A society in this kind of situation would be likely to register a high level of social tension. At the same time, however, the degree of income dispersion may be relatively low. Readers who are sceptical of this point are advised to consult the example included in the introduction to identify the conceptual differences between inequality and polarization.

This issue is particularly relevant in the present context, since numerous studies have stressed the links between social tension, political instability and macroeconomic performance (e.g. VENIERIS AND GUPTA, 1986; ALESINA and PEROTTI, 1996; BENHABIB and RUSTICHINI, 1996). As already mentioned, income polarization generates social tension, which tends to increase socio-political instability. In turn, there are various reasons why a high level of socio-political instability should have a negative impact on economic growth (BARRO, 1991; ALESINA et al., 1996). On the one hand, it should be noted that individual investment decisions are affected by the degree of uncertainty about the political and legal environment. Furthermore, socio-political instability disrupts market activities and labour relations, and may therefore have negative repercussions on aggregate productivity.

Additionally, it is worth mentioning that the recent popularity of the notion of polarization is originally linked to the shrinking of the middle class observed in several developed countries from the late 1970s onwards (e.g. HORRIGAN and HAUGEN, 1988; LEVY and MURNANE, 1992). At this juncture it is pertinent to recall that the 
importance of a large middle class for economic development is well documented in the literature (LANDES, 1998; EASTERLY, 2001a). For example, ADELMAN and NORRIS (1967, p.30) point out that "in the economic development of Western Europe, the middle classes were a driving force." In fact, these authors mention that "it is clear from many country studies that the growth of a robust middle class remains of crucial importance in contemporary low-income nations." According to these arguments, a higher share of income for the middle class is associated with more investment, better economic policies and, therefore, higher growth rates (EASTERLY, 2001b).

From a methodological point of view, it should be emphasized that the empirical analyses carried out so far to investigate the impact of the middle class size on economic performance supplement the information provided by conventional inequality measures with the employment of quantile income shares (e.g. ALESINA and PEROTTI, 1996; PANIZZA, 2002; PARTRIDGE, 2005). However, as clearly highlighted by WOLFSON (1994), these indicators do not provide an accurate picture of possible changes in the middle class. Accordingly, formal polarization indices should be used in this context, as has been done in this paper.

\section{Regional growth and income polarization in the $\mathrm{EU}$}

This article aims to examine the relationship between income polarization and regional growth in 61 EU regions over the period 1993-2003. There are at least two reasons to justify the analysis of this issue in the case of the EU regions. On the one hand, as mentioned in the introduction, as far as we are aware, the possible impact of income polarization on economic performance has not been examined to date in any of the numerous works devoted to investigating the determinants of EU regional growth. Accordingly, our study will allow us to complete the literature on spatial disparities in 
the European context. On the other hand, and leaving this aside, the use of regional data is particularly advisable in this type of analysis, since cross-country studies on the relationship between income distribution and macroeconomic performance are affected by the problems raised by the quality and comparability of the microdata employed (PANIZZA, 2002).

\subsection{Growth patterns in the EU: A regional typology}

Taking our objective into account, we began our analysis by examining the growth patterns of the sample regions during the study period. According to this strategy, we proceeded to construct a spatial typology based on the relationship between the regional growth rates for the time frame considered and the regional distribution of per capita GDP in 1993. Before commenting our results it should be noted that, following the approach adopted among others by BEUGELSDIJK and VAN SCHAIK (2005) and RODRÍGUEZ-POSE and VILALTA-BUFI (2005), all the data used in our analysis were normalized nationally. Thus, the growth rates and initial per capita GDP were expressed in relation to the national average in each case. This allows us to remove from the results of the analysis the influence of the distortions associated with the national dimension, the potential importance of which has been repeatedly pointed out in the literature (QUAH, 1996; EZCURRA et al., 2005). This data transformation also has the advantage of minimizing spatial autocorrelation problems (RODRÍGUEZ-POSE, 1999; GIL et al., 2004). Nevertheless, since regional data are normalized nationally, it should be mentioned that our study provides no information about the possible presence of convergence and divergence processes at the country level. This is not a major drawback in the present context, however, given that most of the current regional inequality in terms of per capita GDP in the EU is within, rather than across, member states (PUGA, 2002). 


\section{[INSERT FIGURE 1 AROUND HERE]}

Figure 1 summarizes the results obtained when we classified the sample regions into four categories according to their initial level of development and their growth rate throughout the time interval considered (RODRÍGUEZ-POSE and VILALTA-BUFI, 2005). As can be observed:

- 10 regions (19\% of the population in 1993) registered growth rates above the national average over the study period, despite having a level of per capita GDP above the national average in 1993 ("Winning regions"). This group includes the regions of northern and central Italy, as well as several areas scattered across the various countries, such as South East in the United Kingdom, Noreste in Spain or Centre-Est in France. The trend followed by some of these regions is linked to certain tertiary activities with high productivity levels (EUROPEAN COMMISSION, 1999). Likewise, this category also includes several regions characterized by the presence of a relatively dynamic manufacturing sector, which has been decisive in consolidating their relevant positions in today's increasingly competitive and integrated markets (RODRÍGUEZ-POSE, 1998).

- 17 regions (26\% of the population in 1993 ), while starting the period with a low level of per capita GDP with respect to their national average, achieved aboveaverage economic growth between 1993 and 2003 ("Catching-up regions"). This is the case of some of the least favoured areas of Spain and Greece, western and southern France, several central and southern regions of the United Kingdom and the Länder of the former German Democratic Republic. Despite their heterogeneity, it is interesting to note that most of these regions experienced 
over the sample period a transfer of productive resources from agriculture and manufacturing towards services. Taking into account existing differences in sectoral productivities, this process of structural change enabled them to narrow their economic development gap with the national average (PACI, 1997; GIL et al., 2002).

- 18 regions (34\% of the population in 1993) which, despite having begun the period with above national average per capita GDP, registered slower than average growth throughout the time interval considered ("Falling behind regions"). This group is formed by some of the main urban centres of Europe, such as Brussels, Berlin, Hamburg, Île de France or Lazio. Although there are some exceptions, the rate of economic growth in most of these regions has been high enough over the last few decades to place them currently among the most developed areas of the EU. The lack of dynamism registered by these regions between 1993 and 2003 may have to do with the possible presence in these large urban centres of congestion costs as a result of excessive agglomeration (THISSE, 2000), which may have had a negative effect on their economic growth rate.

- 16 regions (21\% of the population in 1993) exhibit below-national-average initial levels in both per capita GDP and rate of economic growth ("Losing regions"). This group includes several areas with a relatively important presence of manufacturing activities, currently immersed in a variety of industrial reconversion processes (CUADRADO-ROURA et al., 2000). As examples we might mention northern England or Wales in the United Kingdom, Wallonia in Belgium, or Niedersachsen in Germany. This group also includes a number of regions located in the southern periphery of the EU with relatively large 
agricultural sectors. Such is the case, for example, of Sicilia and Sardegna in Italy, or Kentriki Ellada in Greece.

Despite the fact that any attempt to fix a specific number of regional categories in this context inevitably represents a simplified view of the facts, the typology just presented provides a reasonably realistic representation of the trends registered by the EU regions between 1993 and 2003. Although the nature of this analysis implies that the conclusions should be treated with caution, the study carried out reveals that the sample regions exhibited a heterogeneous behaviour in terms of economic performance during the study period, which gives a clear indication of the complexity of regional growth patterns in the EU (RODRÍGUEZ-POSE, 1998).

\subsection{The measurement of income polarization}

Regardless of all other considerations, the regional typology drawn from Figure 1 clearly shows that there were relatively major differences in the growth patterns of the regions considered over the period 1993-2003. In order to investigate the issue in more detail, this article aims to examine the possible contribution of income polarization to regional growth in the EU. In this respect, it needs to be said that, to best of our knowledge, this factor has so far remained unexplored in the large body of existing research into the determinants of European regional growth processes.

In order to achieve our aim, we need to estimate the degree of polarization of income distribution registered by the various sample regions. In this respect, it should be mentioned that throughout the last decade different authors have derived a set of polarization indices that might be employed for the purposes of the present article (WOLFSON, 1994; WANG and TSUI, 1999; CHAKRAVARTY and MAJUMDER, 2001). Within this framework, we decided to use the polarization measures proposed by ESTEBAN and RAY (1994) and ESTEBAN et al. (2007), since this approach is the 
only one in which the analysis explicitly incorporates the error generated when partitioning the original distribution into various groups in order to quantify the level of polarization.

According to ESTEBAN and RAY (1994), the degree of polarization of a distribution $f$ into a given number of groups can be obtained by means of the following expression:

$$
P^{E R}(\delta, \rho)=\sum_{i=1}^{n} \sum_{j=1}^{n} p_{i}^{1+\delta} p_{j}\left|\mu_{i}-\mu_{j}\right|
$$

where $\mu_{i}$ and $p_{i}$, respectively, denote the conditional mean and the population share of group $i$. Likewise, $\delta$ is a parameter that captures the degree of sensitivity of $P^{E R}$ to polarization, the value of which falls in the interval $[1,1.6]$ in order to be consistent with a set of axioms (see ESTEBAN and RAY (1994) for further details). As can be observed from expression (1), the level of polarization in the distribution under consideration depends on the average income gaps between the various groups and their relative sizes. Before going any further, it is worth noting that the proposed measure of polarization bears an obvious likeness to one of the indicators most commonly used in the traditional literature on inequality, the Gini index, $G$. Nevertheless, the fact that in expression (1) $p_{i}$ is raised to $(1+\delta)$ means that the measure of polarization will, in practice, follow a different pattern from that of the Gini index. In particular, the higher the value adopted by $\delta$, the greater the conceptual division between the inequality and polarization measures.

Before applying this measure, however, it is first necessary to define a simplified representation of the original distribution into a set of $n$ exhaustive and mutually exclusive groups, $\rho=\left(z_{0}, z_{1}, \ldots, z_{n} ; \mu_{1}, \ldots, \mu_{n} ; p_{1}, \ldots, p_{n}\right)$, the boundaries of which are given by income intervals of the form $\left[z_{i-1}, z_{i}\right]$, for $i=1, \ldots, n$. This will involve a certain degree of error, however, as this partition will generate some loss of information, 
depending on the level of income dispersion in each of the various groups considered. Taking this into account, the generalized measure of polarization proposed by ESTEBAN et al. (2007) is obtained after correcting the $P^{E R}$ index applied to the simplified representation of the original distribution with a measure of the grouping error, $\varepsilon(f, \rho)$. That is,

$$
P^{E G R}(f, \delta, \rho, \lambda)=P^{E R}(\delta, \rho)-\lambda \varepsilon(f, \rho)
$$

where $\lambda \geq 0$ is a parameter representing the weight assigned to the error term in expression (2).

Nonetheless, it is important to bear in mind that when dealing with income distributions, there are no unanimous criteria for establishing the precise demarcation between the different groups. To address this problem, ESTEBAN et al. (2007) use the algorithm proposed by DAVIES and SHORROCKS (1989) in order to find the optimal partition of the original distribution into a given number of groups, $\rho^{*}$. This means selecting the partition that minimizes the Gini index value of within-group inequality, $G(f)-G\left(\rho^{*}\right)^{\mathrm{iii}}$. Given that $\varepsilon\left(f, \rho^{*}\right)=G(f)-G\left(\rho^{*}\right)$, the generalized measure of polarization proposed by Esteban et al. (2007), therefore, can be expressed as:

$$
P^{E G R}\left(f, \delta, \rho^{*}, \lambda\right)=P^{E R}\left(\delta, \rho^{*}\right)-\lambda\left[G(f)-G\left(\rho^{*}\right)\right]
$$

\subsection{Empirical evidence for the European regions}

Following the above methodology, we estimated the level of income polarization registered by the EU regions, using the information provided by various partitions of the original distributions into two, three and four groups. In order to check the robustness of the results, different degrees of sensitivity to polarization were considered in our analysis. Specifically, $\delta=1,1.3,1.6$. Likewise, as in ESTEBAN et al. (2007), in all 
cases $\lambda=1^{\text {iv }}$.

Before discussing the results, it should be noted that the various partitions used were obtained by applying the algorithm proposed by DAVIES and SHORROCKS (1989), thus minimizing within-group dispersion. In relation to this, it needs to be said that when the different income distributions of the sample regions are divided into two groups according to this procedure, it is possible to explain on average $70 \%$ of the total inequality measured by the Gini index. In turn, the three-group partition provides a $16 \%$ increase in explanatory power, given that average between-group inequality is in this case $86 \%$ of overall dispersion. Finally, when the various income distributions are classified into four groups, the differences between them explain $92 \%$ on average of total inequality, which is $6 \%$ more explanatory power than the three-group classification.

\section{[INSERT TABLE 1 AROUND HERE]}

Table 1 presents the set of generalized measures of polarization calculated for each region in the two-, three-, and four-group cases, taking net per capita income of the various households in 1993 as the reference variable in the analysis. In order to provide additional information on the results, Table A1 in the Appendix also shows the values of the two $P^{E G R}$ components according to expression (3): the polarization of the simplified representations of the original distribution, and the degree of within-group dispersion. As can be observed in Table 1, within each partition there is clearly a strong similarity between the various regional rankings generated from the different values assigned to the polarization sensitivity parameter $\delta$ (see Table A2 in the Appendix for further details). Furthermore, it is worth noting that, although there are certain 
differences in the case of some specific regions depending on the partition considered, all the measures calculated can be seen to coincide in showing a considerable variation in the degree of polarization within the sample regions. Thus, for example, in the case of a partition of the original distributions into two groups and with $\delta=1.3, P^{E G R}$ ranges between 0.055 for Sachsen-Anhalt and 0.149 for Açores, which clearly highlights the relevance of regional disparities in this context. In any event, it should be mentioned that close observation of the values shown in Table 1 reveals that, despite some exceptions can be observed, the least stratified income distributions tend to be found in central and northern regions of the EU, while the areas with the highest polarization levels are located mainly in the southern periphery.

Having reached this point, it is worth pausing for a moment to analyse the relationship between polarization and inequality in the EU regions. To this end, we decided to examine the degree of statistical association between the generalized measures of polarization calculated above and various indices commonly used in the literature to capture the level of dispersion of the distribution object of analysis. In this way, we aim to shed light on the empirical relevance of polarization in relation to the more usual concept of inequality.

Before continuing any further, it is worth recalling that the results of inequality studies may differ, at times substantially, according to which measures are employed in the analysis (SEN, 1973). Given the obvious difficulty that arises from the fact that different indicators may give different orderings of the distribution to be compared, it seems reasonable to check the robustness of our results against various inequality measures. Specifically, in this article we decided to consider the information provided by the following indicators: the Gini index, $G$; the two measures proposed by Theil (1967) in the information theory context, $G E(0)$ and $G E(1)$; and the normative index 
derived by Atkinson (1970) with values of the inequality aversion parameter equal to 0.5 and 2, $A(0.5)$ and $A(2)$. It should be noted that all the indices selected are independent of scale and population size, and they all fulfil the Pigou-Dalton transfer principle for the whole definition domain of income (COWELL, 1995).

\section{[INSERT TABLE 1 AROUND HERE]}

Table 1 displays the Kendall's rank correlation coefficients between these inequality measures and $P^{E G R}$. As can be observed, the estimated coefficients are positive and statistically significant in all cases. Nevertheless, the magnitude of the values obtained reveals clearly that the there are differences between the regional rankings generated from $P^{E G R}$ and the various inequality measures. In fact, this finding does not depend on the number of groups considered in the analysis or the value assigned to the polarization sensitivity parameter $\delta$. Furthermore, it is interesting to note how the degree of association between inequality and polarization decreases as $\delta$ increases. The analysis carried out therefore suggests that, beyond the conceptual distinction mentioned in the introduction, there are differences between polarization and inequality in the EU regions. This conclusion reinforces the need for separate approaches to the study of these two phenomena, which is consistent with the perspective adopted in this article.

In any event, the question that emerges at this point is whether there exists a possible link between the economic performance of the regional categories established in the previous subsection and their level of income polarization. In order to investigate this issue, it is useful to check for any potential differences in the degree of income polarization characterizing the regions of the various groups. To this end, an analysis of the variance of the different polarization measures calculated was performed, taking the 


\section{[INSERT TABLE 2 AROUND HERE]}

regional typology drawn from Figure 1 as the reference. As a prior step, following the strategy adopted in subsection 3.1, the various polarization indices were normalized according to the national average. This is particularly advisable in the present context, because of the major role played by the national component in explaining the spatial distribution of personal income in the EU regions (EZCURRA and PASCUAL, 2005).

The results, which are summarized in Table 2, are very similar for the different polarization measures estimated above, irrespective of the specific partition considered in each case and the value assigned to the parameter $\delta$. Thus, the various $\mathrm{F}$ tests carried out reveal statistically significant differences in the average polarization levels of the various regional categories considered. It is particularly interesting to observe how the most dynamic regions during the sample period ("Winning regions" and "Catching-up regions") display below-national-average income polarization in 1993. This does not hold for the other two categories. Indeed, the relative low growth over the study period experienced by the "Falling behind regions" and "Losing regions" coincides with above-national-average levels of income polarization in 1993.

\section{Econometric analysis}

The empirical evidence presented above suggests the possible presence of a relationship between income polarization and economic growth in the EU regions. In order to complete the results obtained so far, this section is devoted to a more detailed investigation of the issue, using a reduced-form growth model, which can be written in matrix notation as: 
$\Delta Y_{t_{0}, t_{1}}=\alpha+\beta P_{t_{0}}+X_{t_{0}} \phi+\varepsilon$

where $\Delta Y$ is the vector of the annual growth rates of per capita GDP between $t_{0}$ and $t_{1}$ in the regions considered $\left(t_{0}=1993\right.$ and $\left.t_{1}=2003\right), P$ is the value of the polarization measure used to capture the level of income stratification within each region, and $X$ is a set of additional variables controlling for other factors that are assumed to influence regional growth. Finally, $\varepsilon$ is the disturbance term. Note that, following standard practice in the convergence literature, this model is based on the assumption that economic growth is converging to an equilibrium growth path that is a function of the initial conditions (DURLAUF and QUAH, 1999; MAGRINI, 2004).

Before continuing, it is worth pausing for a moment to describe the series of variables that make up the matrix $X$. In this respect, while the choice of these variables is theoretically well grounded, it ultimately depends on the availability of reliable statistical data for the geographical setting on which our study is focused. Thus, following the convention in the literature on economic growth, the initial level of per capita GDP was used to control for economic convergence across regions (BARRO and SALA-I-MARTIN, 1991, 1992). The inclusion of this variable in the model allows us to determine whether poor regions grew faster than richer ones during the study period, thus providing information on the dynamics of regional disparities in our sample between 1993 and 2003.

In addition, we examined the role played in this context by regional specialization. In fact, the influence of the sectoral composition of economic activity on regional growth processes is well known in the literature (see NEVEN and GOUYETTE (1995), PACI (1997) or GIL et al. (2002), for evidence on the EU case). Hence, it is reasonable to consider the possibility of a relationship between the productive structure of the different regions and their economic performance during the study period. Accordingly, 
our model includes the regional employment shares in agriculture, manufacturing, market services and non-market services at the beginning of the study period. Note, moreover, that, despite the process of convergence in regional productive structures that has characterized the European economy during recent decades, considerable differences persist in the patterns of regional specialization across the EU regions (EZCURRA et al., 2006).

It is also worth mentioning that the literature has repeatedly stressed the theoretical importance of human capital in explaining economic growth (MANKIW et al., 1992; BARRO and SALA-I-MARTIN, 1995). Specifically, economies characterized by higher human capital endowment are considered to have greater development potential than those with insufficient and inadequate human resources. Likewise, it should be noted that the relationship between income distribution and human capital investment decisions has been highlighted in various studies (GALOR and ZEIRA, 1993). This is of particular relevance in the context of this article, since it raises the possibility that the polarization measures may be capturing the effect of differences in human capital stock levels on regional growth. For this reason, we considered the possibility of controlling our estimations for this factor. This is no easy task, however, due to lack of reliable comparable data on human capital for the European regions at the beginning of our study period. In order to overcome this important limitation, we decided to follow the strategy adopted by RODRÍGUEZ-POSE and VILALTA-BUFI (2005) and use the ECHP to obtain information on the educational stock of the various regions considered in the analysis. Thus, for every region in the sample, we calculated the percentage of survey respondents with completed secondary and tertiary education at the beginning of the study period, and introduced these variables into model (4).

We also analysed the possible influence in this context of agglomeration economies 
(FUJITA and THISSE, 2002). To this end, we considered the information provided by two different variables: population density and market potential. In this respect, it is worth mentioning that population density is widely used in the literature to measure the degree of concentration of economic activity in a given area (LÓPEZ-BAZO, 2003). Additionally, a market potential index was estimated for each region to capture the fact that the potential demand for goods and services in a given location is influenced by its accessibility to consumers (HANSON, 1998). The "new economic geography" models lend theoretical support for the use of an index of this type (KRUGMAN, 1992), while various recent studies have underlined its empirical relevance (BRÜLHART et al., 2004). In this article, the market potential of each region was defined, according to HARRIS (1954), as the sum of the purchasing power of all other EU regions weighted by the inverse distance, to capture the effect of transport costs.

It is worth mentioning that, as in the previous sections, all data on the variables used in the econometric analysis were normalized nationally. In relation to this, it should be noted that this data transformation eliminates the possible influence of country-specific factors, thus reducing the potential impact of the omitted-variable bias in the results. Likewise, an important advantage of the chosen specification is that there should be no direct endogeneity, since all the explanatory variables are measured at the beginning of the study period (PARTRIDGE, 1997, 2005; LI and ZOU, 1998; RODRÍGUEZ-POSE and VILALTA-BUFI, 2005). For this reason, Ordinary Least Squares (OLS) were used in the estimations carried out. Taking into account that the inclusion of multiple control variables may cause multicollinearity problems, we decided to estimate various alternative versions of model (4) to test for robustness (PANIZZA, 2002; PARTRIDGE, 2005). 
[INSERT TABLE 3 AROUND HERE]

Table 3 reports the results obtained when the measure of generalized polarization is calculated for each region from a partition of the income distribution into two groups. As can be observed, the inclusion of the degree of income polarization in our reducedform growth model yields interesting results. Specifically, the estimated coefficients on the $P^{E G R}$ index are negative and statistically significant in all cases, which means that high initial income polarization is correlated with low economic growth in the ensuing years. This result is in fact robust to the inclusion in the analysis of additional explanatory variables. In any event, it needs to be said that the estimates carried out reveal that the impact of income polarization on economic growth decreases as the value assigned to the polarization sensitivity parameter $\delta$ increases.

With respect to the control variables mentioned above, Table 3 indicates that the coefficient on the initial per capita GDP is negative and statistically significant in the various specifications considered, signalling the existence of a process of regional convergence in terms of development within the sample countries. This is consistent with the information provided by Figure 1, according to which $58 \%$ of the regions considered tend to fall into the "Catching-up" or "Falling behind" categories. The analysis carried out also reveals that industry mix is a relevant factor when it comes to explaining regional performance in the European context. Specifically, regions specializing in manufacturing activities at the beginning of the sample period registered low growth rates in relative terms over the following years, which highlights the numerous problems raised by industrial reconversion processes in the EU (EUROPEAN COMMISSION, 1999). In turn, the presence of a relatively large non-market service sector has a negative impact on economic performance. This result is consistent with the 
empirical evidence presented by RODRÍGUEZ-POSE and FRATESI (2004b), who stress the fact that European peripheral regions with high levels of public employment registered moderate growth rates during the last two decades. Additionally, the information provided by Table 3 suggests the possible influence of the educational stock of the various regions in this context. In fact, the two human-capital controls are positively correlated with the dependent variable, although only the percentage of population with tertiary education is statistically significant. Finally, it is worth mentioning that the two variables used to capture the relevance of agglomeration economies, population density and market potential, are not statistically significant. In any event, these results should be viewed with some degree of caution in light of the values of the condition numbers.

As mentioned above, endogeneity should not be a direct concern in this context, since the explanatory variables are measured in all cases at the beginning of the sample period. Nevertheless, it is worth noting that the initial per capita GDP that appears on the right hand side of model (4) is also used to calculate the dependent variable (LI and ZOU, 1998; FORBES, 2000). Taking this into consideration, and following PARTRIDGE (2005), we decided to remove the initial per capita GDP level from the list of regressors in model (4). There are in fact various additional reasons to justify this alternative specification. Specifically, from a theoretical point of view, it should be recalled that the analysis of the convergence hypothesis based on cross-sectional growth regressions has been criticized by QUAH (1993) as an example of the Galton's fallacy, highlighting that the effect of initial per capita GDP on economic growth could be simply spurious (DURLAUF and QUAH, 1999). In addition, the initial per capita GDP is likely to be correlated with the majority of the remaining regressors, which might make it difficult to analyse the true effect of the different explanatory variables on 
economic performance. As can be checked in columns 7 and 8 in Table 3, the results when the initial per capita GDP is omitted from the analysis are very similar to those just described. In particular, from the point of view of this article, the most relevant issue is that the polarization indices remain negative and statistically significant. Additionally, we considered the possibility that our results may be driven by the presence of outliers. Nevertheless, the information supplied by the standardized residuals from the different estimated versions of model (4) indicates that the observed negative correlation between income polarization and economic growth is not caused by potential outliers. Additionally, it must not be overlooked that the presence of spatial dependence in the error term of model (4) could bias our results (ANSELIN, 1988). For this reason, we proceeded by performing a spatial autocorrelation test proposed by KELEJIAN and ROBINSON $(1992,1997)$, which is particularly suitable for relatively large geographical units such as NUTS-1 regions. To calculate this test, it was first necessary to construct a spatial weights matrix capturing the degree of interdependence between the various regions. Specifically, we considered a row-standardized spatial weights matrix based on the squared inverse distance between the centroids of the sample regions. In relation to this, it should be mentioned that this spatial weights matrix is exogenous to the model, which precludes the identification problems raised by MANSKI (1993). However, as can be observed in Table 3, the results of this test lead in all cases to the acceptance of the null hypothesis of absence of residual spatial dependence in the various estimated versions of model (4).

From a theoretical point of view, it is worth noting that the observed correlation between income polarization and economic performance may be sensitive to the number of groups employed to construct the simplified representation $\rho^{*}$ used to calculate $P^{E G R}$. Taking this into account, the estimates were repeated using the various 
generalized measures of polarization obtained above for the three- and four-group cases (see Table 1), as an alternative to the two-group classification used so far in this section. In this respect, the information provided by Tables 4 and 5 shows that the estimated coefficients on the different polarization measures continue to be negative and statistically significant in all cases. Therefore, the negative relationship detected between income polarization and economic growth does not depend on the specific number of groups employed to characterize the income distribution in the European regions.

[INSERT TABLE 4 AROUND HERE]

[INSERT TABLE 5 AROUND HERE]

Having reached this point, it should be recalled that, according to expression (3), the value of $P^{E G R}$ is derived from two factors: the polarization level of the simplified representation of the original distribution, and the degree of within-group dispersion weighted by the parameter $\lambda$. In order to complete our previous results, we examined the influence on economic performance of these two components of the generalized measure of polarization proposed by ESTEBAN et al. (2007). To this end, we considered several alternative specifications of model (4), including $P^{E R}$ and $\varepsilon$ instead of $P^{E G R}$ in the list of regressors. The results obtained are summarized in Table 6 . As can be observed, $P^{E R}$ and $\varepsilon$ are statistically significant in all cases, confirming the relevance of both factors in this context. Specifically, the analysis carried out shows that the level of polarization of the simplified representation of the original distribution is negatively correlated with regional growth, regardless of the number of groups 


\section{[INSERT TABLE 6 AROUND HERE]}

\section{Conclusions}

Throughout the preceding pages, we have examined the possible link between income polarization and economic performance in 61 EU regions during the period 1993-2003. As far as we are aware, this factor had never before been considered in any of the numerous works devoted to explaining regional growth processes in the European setting. Nevertheless, as we have shown, there are various theoretical arguments that suggest that income polarization may affect economic growth. To study this issue, we have estimated the degree of income polarization registered within the EU regions by applying the approach proposed by ESTEBAN and RAY (1994) and ESTEBAN et al. (2007). The different measures calculated show that polarization levels vary considerably across the EU. In this respect, it is worth mentioning that, despite some exceptions can be observed, the regions with the most polarized income distributions tend to be located mainly in the southern periphery of the Union.

Although the limited time-frame and the nature of the study implies that any conclusions should be treated with caution, our analysis indicates that economic growth is negatively correlated with the level of income polarization at the beginning of the study period. This finding is in fact robust to the inclusion in the analysis of additional explanatory variables, such as the initial level of per capita GDP, the sectoral 
composition of economic activity, human capital stock, population density and market potential. Likewise, the observed negative correlation between income polarization and economic growth does not depend on the number of groups used to analyse the degree of income stratification within the sample regions.

The analysis carried out in this article raises a series of implications of potential interest to European regional policy-makers, whose ultimate goal is to guarantee economic and social cohesion within the EU by reducing territorial imbalances (EUROPEAN COMMISSION, 2004). The empirical evidence presented in this respect appears to suggest that public intervention through programs planned to reduce the degree of polarization in the income distribution may help to boost regional growth, which is a possibility that has so far remained unexplored by EU regional policy designers. Nevertheless, this recommendation should be considered with some degree of caution, since it cannot be overlooked that the redistribution of resources could introduce distortions in individual investment decisions, which might ultimately hamper economic growth (ALESINA and RODRIK, 1994; PERSON and TABELLINI, 1994). Prior to the introduction of specific redistributive policies, therefore, a detailed analysis should be made of their potential effect on economic performance.

Additional extensions to our work are not difficult to conceive. Some of them relate directly to the improvement of existing data on income distribution within the various EU regions. As we have been able to observe in this article, the recent development of the ECHP is an important step towards this objective. However, the time frame covered by the ECHP is relatively short, which prevents the long term analysis of the relationship between income polarization and economic growth, and limits the possibility of applying panel data techniques in this context. Likewise, future research should pay particular attention to the need to analyse the various theoretical mechanisms 
explaining the influence of the degree of income polarization on the economic performance of EU regions. This would allow us to identify exactly the channels through which income polarization affects economic growth, which is an issue especially relevant from the economic policy perspective.

\section{Acknowledgments}

The authors would like to thank two anonymous referees for their helpful comments and suggestions. The usual disclaimer applies. Financial support from Spanish MEC (Project SEJ2005-08738-C02-01 and Programme Juan de la Cierva) is gratefully acknowledged.

\section{References}

ADELMAN I. and MORRIS C.T. (2001) Society, Politics and Economic Development: A Quantitative Approach. Baltimore: John Hopkins Press.

AGHION P., CAROLI E. and GARCIA-PEÑALOSA C. (1999) Inequality and Economic Growth: The Perspective of the New Growth Theories, Journal of Economic Literature, 37, 1615-1660.

ALESINA A. and RODRIK D. (1994) Distribution Politics and Economic Growth, Quarterly Journal of Economics 109, 465-490.

ALESINA A. and PEROTTI R. (1996) Income Distribution, Political Instability and Investment, European Economic Review, 81, 1170-1189.

ALESINA A., OZLER S., ROUBINI N. and SWAGEL P. (1996) Political instability and economic growth, Journal of Economic Growth 1, 189-211.

ANDERSON G. (2004) Toward an empirical analysis of polarization, Journal of Econometrics 122, 1-26.

ANSELIN L. (1988) Spatial Econometrics: Methods and Models. Kluwer Academic 
Publishers, Dordrecht.

ATKINSON A.B. (1970) On the measurement of inequality, Journal of Economic Theory 3, 244-263.

ATKINSON A.B. and BRANDOLINI A. (2001) Promise and pitfalls in the use of secondary data-sets: Income inequality in OECD countries, Journal of Economic Literature 34, 771-799.

BARRO R. (1991) Economic growth in a cross-section of countries, Quarterly Journal of Economics 106, 407-444.

BARRO R. (2000) Inequality and Growth in a Panel of Countries, Journal of Economic Growth 5, 5-32.

BARRO R. and SALA-I-MARTIN X. (1991) Convergence across states and regions, Brooking Papers on Economic Activity 1, 107-182.

BARRO R. and SALA-I-MARTIN X. (1992) Convergence, Journal of Political Economy 100, 407-443.

BARRO R. and SALA-I-MARTIN X. (1995) Economic Growth. Mc-Graw-Hill, New York.

BEACH C.M., CHAYKOWSKI R.P. and SLOTSVE G.A. (1998) Inequality and polarization of male earnings in the US 1968-1992, North American Journal of Economic and Finance 8, 135-151.

BENABOU R. (1996) Inequality and growth, NBER Macroeconomics Annual, 11-73.

BENHABIB J. and RUSTICHINI A. (1996) Social Conflict and Growth, Journal of Economic Growth 1, 129-146.

BEUGELSDIJK S. and VAN SCHAIK T. (2005) Differences in social capital between 54 Western European regions, Regional Studies 39, 1053-1064.

BILBAO-OSORIO B. and RODRÍGUEZ-POSE A. (2004) From R\&D to Innovation 
and Economic Growth in the EU, Growth and Change 35, 434-455.

BRÜlHART M., CROZET M. and KOENIG P. (2004) Enlargement and the EU Periphery: The impact of changing market potential, World Economy 27, 853-875.

CHAKRAVARTY S.R. and MAJUMDER A. (2001) Inequality, polarization and welfare: Theory and applications, Australian Economic Papers 40, 1-13.

CLARKE G. (1995) More evidence on income distribution and growth, Journal of Development Economics 47, 403-427.

COWELL F. (1995) Measuring Inequality, 2nd Edition, LSE Handbooks in Economics. London: Prentice Hall.

CUADRADO-ROURA J.R., MANCHA-NAVARRO T. and GARRIDO-YSERTE R. (2000) Regional productivity patterns in Europe: An alternative approach, Annals of Regional Science 34, 365-384.

DAVIES J.B. and SHORROCKS, A. F. (1989) Optimal grouping of income and wealth data, Journal of Econometrics 42, 97-108.

DURLAUF S.N. and QUAH D. (1999) The new empirics of economic growth. In TAYLOR J.B. and WOODFORD M. (eds.): Handbook of Macroeconomics, vol. 1A, pp. 231-304. North-Holland, Amsterdam.

DURO J.A. (2005) International income polarization: a note, Applied Economics Letters $12759-762$.

EASTERLY W. (2001a) The middle class consensus and economic development, Journal of Economic Growth 6, 317-335.

EASTERLY W. (2001b) The Elusive Quest for Growth. Cambridge (MA): MIT Press.

ECKEY H.F. and TÜRCK M. (2006) Convergence of EU regions. A literature report, Institut für Volkswirtschaftslhere Working Paper 80/06, Kassel Universität.

EICHER T.S. and TURNOVSKY S.J. (editors) (2003) Inequality and Growth: Theory 
and Policy Implications. Cambridge (MA): MIT Press.

ESTEBAN J.M. and RAY D. (1994) On the measurement of polarization, Econometrica 62, 819-851.

ESTEBAN J.M., GRADÍN C. and RAY D. (2007) Extension of a measure of polarization with an application to the income distributions of five OECD countries, Journal of Income Inequality 5, 1-19.

EUROPEAN COMMISSION (1999) Sixth Periodic Report on the Social and Economic Situation of the Regions in the European Union. European Commission, Brussels.

EUROPEAN COMMISSION (2004) Third report on economic and social cohesion. European Commission, Brussels.

EUROSTAT (1996) The European Community Household Panel (ECHP): Volume 1 Survey, Methodology and Implementation. European Commission, Luxembourg.

EUROSTAT (1998) ECHP data quality, Working Group European Community Household Panel, European Commission, Luxembourg.

EUROSTAT (1999) ECHP data quality-Second report, Working Group European Community Household Panel, European Commission, Luxembourg.

EZCURRA R. and PASCUAL P. (2005) Is there convergence in income inequality levels among the European regions?, Applied Economics Letters 12, 763-767.

EZCURRA R., GIL C., PASCUAL P. and RAPÚN M. (2005) Regional inequality in the European Union: Does industry mix matter?, Regional Studies 39, 679-697.

EZCURRA R., PASCUAL P. and RAPÚN M. (2006) Regional specialization in the European Union, Regional Studies 40, 601-616.

FORBES K.J. (2000) A reassessment on the relationship between inequality and growth, American Economic Review 90, 869-887.

FUJITA M. and THISSE J.F. (2002) Economics of Agglomeration. Cambridge 
University Press, Cambridge.

GALOR O. and ZEIRA J. (1993) Income Distribution and Macroeconomics, Review of Economic Studies 60, 35-52.

GIL C., PASCUAL P. and RAPÚN M. (2002) Structural change, infrastructure and convergence in the regions of the European Union, European Urban and Regional Studies 9, 115-135.

GIL C., PASCUAL P. and RAPÚN M. (2004) Regional economic disparities and decentralization, Urban Studies 41, 71-94.

HANSON G. (1998) Market Potential, Increasing Returns, and Geographic Concentration, NBER working paper 6429, National Bureau of Economic Research.

HARRIS C.D. (1954) The Market as a Factor in the Localization of Industry in the United States, Annals of the Association of American Geographers 64, 315-348.

HORRIGAN M.W. and HAUGEN S.E. (1988) The declining middle class: a sensitivity analysis, Monthly Labor Review 111, 3-11.

JENKINS S.P. (1996) Recent trends in the UK income distribution: what happened and why?, Oxford Economic Policy 12, 29-46.

KELEJIAN H.H. and ROBINSON D.P. (1992) Spatial autocorrelation: A new computationally simple test with an application to per capita county policy expenditures, Regional Science and Urban Economics 22, 317-331.

KELEJIAN H.H. and ROBINSON D.P. (1997) Infrastructure productivity estimation and its underlying econometric specifications: A sensitivity analysis, Papers in Regional Science 76, 115-131.

KRUGMAN P. (1992) A Dynamic Spatial Model, NBER working paper 4219, National Bureau of Economic Research.

LANDES D. (1998) The Wealth and Poverty of Nations. New York: Norton. 
LEVY F. and MURNANE R.J. (1992) U.S. earnings levels and earnings inequality: A review of recent trends and proposed explanations, Journal of Economic Literature 30, $1333-1381$.

LI H. and ZOU H. (1998) Income inequality is not harmful for growth: Theory and evidence, Review of Development Economics 2, 318-334.

LÓPEZ-BAZO E. (2003) Growth and convergence across economies: The experience of the European regions. In FINGLETON B., ERAYDIN A. and PACI R. (eds.): Regional Economic Growth, SMEs and the Wider Europe, pp. 49-74. Ashgate, Aldershot.

LÓPEZ-BAZO E., VAYÁ E. and ARTÍS A. (2004) Regional externalities and growth: Evidence from European regions, Journal of Regional Science 44, 43-73.

MAGRINI S. (2004) Regional (Di)Convergence. In HENDERSON V. and THISSE J. (eds.): Handbook of Urban and Regional Economics, vol. IV, pp. 2741-2796. North Holland, Amsterdam.

MANKIW G., ROMER P. and WEIL D. (1992) A contribution to the empirics of economic growth, Quarterly Journal of Economics 107, 407-437.

MANSKI C.F. (1993) Identification of endogenous social effects: The reflection problem, Review of Economic Studies 60, 531-542.

MARTINO G. and PERUGINI C. (2006) Income inequality within European regions: Determinants and effects on growth. Paper presented at the 9th conference of the European Association for Comparative Economics Studies, Brighton (UK), September.

NEVEN D. and GOUYETTE C. (1995) Regional Convergence in the European Community, Journal of Common Market Studies 33, 47-65.

OTTAVIANO G. and PUGA D. (1998) Agglomeration in the global economy: A survey of the new economic geography, The World Economy 21, 707-731. 
PACI R. (1997) More Similar and Less Equal: Economic Growth in the European Regions, Weltwirtschaftliches Archiv 133, 609-634.

PANIZZA U. (2002) Income inequality and economic growth: Evidence from American data, Journal of Economic Growth 7, 25-41.

PARTRIDGE M.D. (1997) Is Inequality Harmful for Growth? Comment, American Economic Review 87, 1019-1032.

PARTRIDGE M.D. (2005) Does income distribution affect U.S. state economic growth, Journal of Regional Science 45, 363-394.

PEROTTI R. (1996) Growth, income distribution and democracy: What the data say, Journal of Economic Growth 1, 149-187.

PERSSON T. and TABELLINI, G. (1994) Is Inequality Harmful for Growth? Theory and Evidence, American Economic Review 84, 600-621.

PUGA D. (2002) European regional policies in light of recent location theories, Journal of Economic Geography 2, 373-406.

PYATT G. (1976) On the interpretation and disaggregation of Gini coefficient, Economic Journal 86, 243-255.

QUAH D. (1993) Galton's fallacy and tests of the convergence hypothesis, Scandinavian Journal of Economics 95, 427-443.

QUAH D. (1996) Regional convergence clusters across Europe, European Economic Review 40, 951-958.

RODRÍGUEZ-POSE A. (1998) The Dynamics of Regional Growth in Europe: Social and political factors. Clarendon Press, Oxford.

RODRÍGUEZ-POSE A. (1999) Convergence or Divergence? Types of Regional Responses to Socio-Economic Change in Western Europe, Tijdschrift voor Economische en Sociale Geografie 90, 363-378. 
RODRÍGUEZ-POSE A. and FRATESI U. (2004a) Between development and social policies: The impact of European Structural Funds in Objective 1 regions, Regional Studies 38, 97-113.

RODRÍGUEZ-POSE A. and FRATESI U. (2004b) Regional economic cycles and the emergence of sheltered economies in the periphery of the European Union, London School of Economics, mimeo.

RODRÍGUEZ-POSE A. and VILALTA-BUFI M. (2005) Education, migration, and job satisfaction: the regional returns of human capital in the EU, Journal of Economic Geography 5, 545-566.

SEN A. (1973) On Economic Inequality. Oxford: Oxford University Press.

THEIL, H. (1967) Economics and Information Theory. Amsterdam: North Holland.

THISSE J.F. (2000) Agglomeration and regional imbalance: Why? And is it bad?, Papers of the European Investment Bank 5, 47-67.

VENIERIS Y. and GUPTA D. (1986) Income distribution and sociopolitical instability as determinants of savings: A cross-sectional model, Journal of Political Economy 94, 873-883.

WANG Y. and TSUI K. (2000) Polarization orderings and new classes of polarization indices, Journal of Public Economic Theory 2, 349-363.

WHITE H. (1980) A heteroskedasticity-consistent covariance matrix estimator and a direct test for heteroskedasticity, Econometrica 48, 817-838.

WOLFSON M. (1994) When inequalities diverge, American Economic Review 84, 353358.

\section{Appendix}

The data on income distribution within the EU regions used in this article were taken 
from the European Community Household Panel (ECHP). The ECHP is a harmonized cross-national longitudinal survey focusing on social and economic conditions in the EU, conducted in various member states under the control of the Statistical Office of the European Communities (Eurostat, 1996). It includes regionally disaggregated data on income, work and employment, poverty and exclusion, education, housing, health, and other social indicators of living conditions. It is important to note that Eurostat (1998, 1999) has checked the reliability of the ECHP data against other national sources. Although existing methodological differences must be taken into account in such comparisons, the results obtained confirm the quality of the ECHP data.

The ECHP is based on a representative panel of individuals and households in the 15 EU member states prior to the 2004 and 2007 enlargements. Note, however, as already stated in the introduction, that the time frame considered in the article is restricted by the scope of the ECHP. In this respect, it is worth mentioning that, while the ECHP survey was first conducted 1994, the personal income data refer to the situation of individuals and households in 1993. For this year there is information in the survey corresponding to 149,306 individuals and 71,367 households.

In order to achieve the aims of the article, we aggregated the ECHP data for 61 NUTS-1 regions belonging to eight countries: Belgium, Germany, Spain, France, Greece, Italy, Portugal and the United Kingdom (see Table 1 for further details) ${ }^{\mathrm{v}}$. The reason for using NUTS-1 regions in the analysis is that no finer level of territorial disaggregation is provided by the ECHP. This should be taken into account when assessing our findings since, as occurs in any analysis based on spatial data, the level of territorial disaggregation used may influence on the results (MAGRINI, 2004).

Additionally, the data on GDP, population and sectoral employment used in the analysis are drawn from the Cambridge Econometrics European regional database. The Eurostat 
Regio database is the prime source of raw data for the Cambridge Econometrics database. However, Regio is seriously lacking in some respects, especially in the case of certain specific countries. For this reason, and in order to achieve comprehensive coverage, Cambridge Econometrics has opted to complete Eurostat data with more detailed information from national statistics offices.

[INSERT TABLE A1 AROUND HERE]

[INSERT TABLE A2 AROUND HERE] 


\section{Figures and Tables}

Figure 1: Growth patterns in the EU throughout the period 1993-2003: A regional typology.
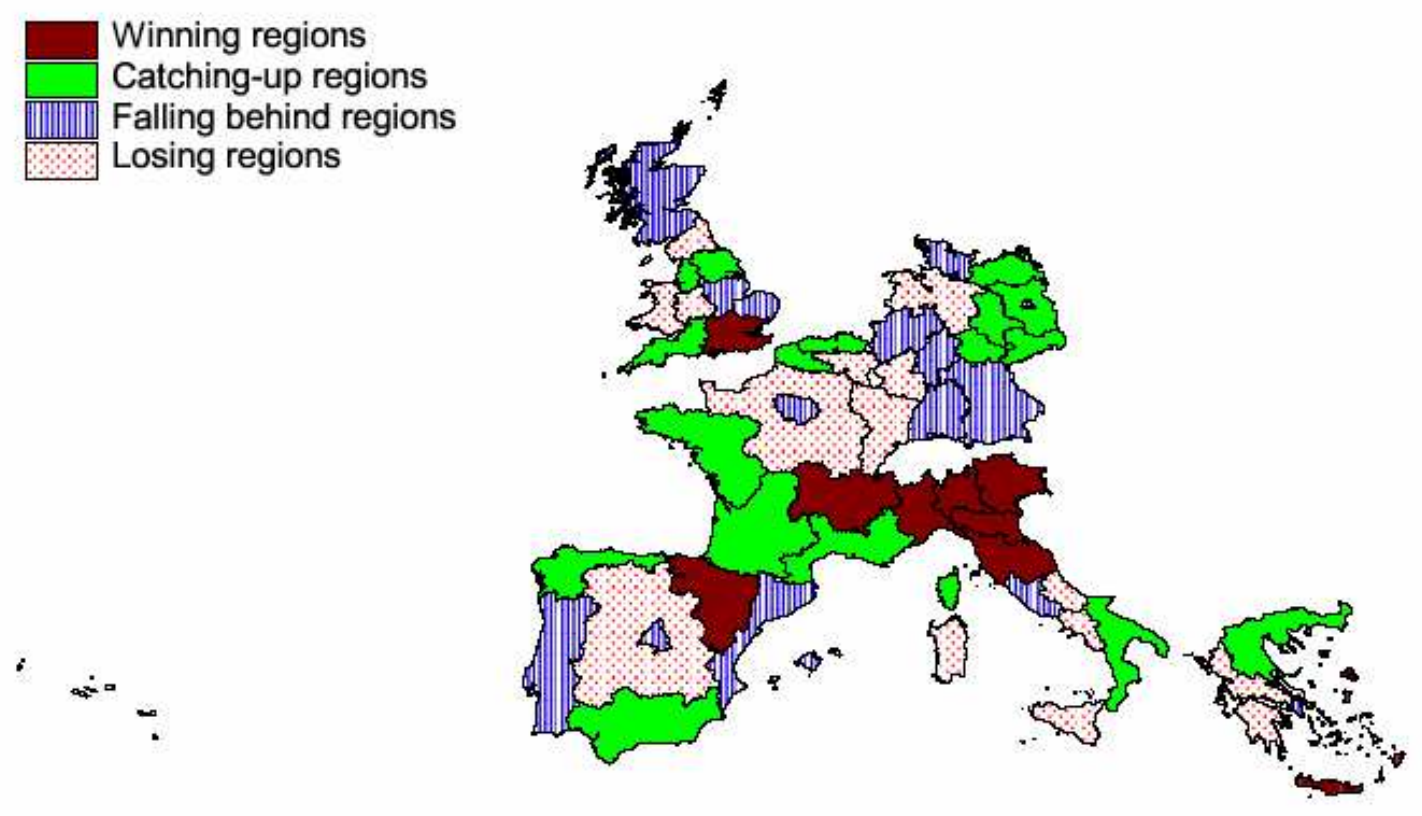

$$
\therefore 0_{0} \not
$$


Table 1: Income polarization in the European regions.

\begin{tabular}{|c|c|c|c|c|c|c|c|c|c|}
\hline \multirow{3}{*}{$\begin{array}{l}\text { Partition } \\
\text { Region } \\
\end{array}$} & \multicolumn{9}{|c|}{ Generalized measure of polarization ( $P^{E G R}$ index $)$} \\
\hline & \multicolumn{3}{|c|}{ Two groups } & \multicolumn{3}{|c|}{ Three groups } & \multicolumn{3}{|c|}{ Four groups } \\
\hline & $\delta=1$ & $\delta=1.3$ & $\delta=1.6$ & $\delta=1$ & $\delta=1.3$ & $\delta=1.6$ & $\delta=1$ & $\delta=1.3$ & $\delta=1.6$ \\
\hline Bruxelles-Brussels (be1) & 0.134 & 0.092 & 0.058 & 0.152 & 0.098 & 0.060 & 0.169 & 0.087 & 0.052 \\
\hline Vlaams Gewest (be2) & 0.119 & 0.082 & 0.053 & 0.127 & 0.081 & 0.048 & 0.111 & 0.067 & 0.038 \\
\hline Région Wallonne (be3) & 0.123 & 0.083 & 0.052 & 0.134 & 0.086 & 0.051 & 0.116 & 0.069 & 0.038 \\
\hline Baden-Württemberg (de1) & 0.122 & 0.084 & 0.053 & 0.126 & 0.080 & 0.048 & 0.112 & 0.068 & 0.039 \\
\hline Bayern (de2) & 0.130 & 0.090 & 0.059 & 0.137 & 0.091 & 0.057 & 0.116 & 0.070 & 0.040 \\
\hline Berlin (de3) & 0.119 & 0.082 & 0.052 & 0.123 & 0.078 & 0.046 & 0.107 & 0.064 & 0.035 \\
\hline Brandenburg (de4) & 0.114 & 0.077 & 0.047 & 0.122 & 0.077 & 0.044 & 0.109 & 0.065 & 0.036 \\
\hline Bremen (de5) & 0.107 & 0.073 & 0.046 & 0.111 & 0.070 & 0.040 & 0.103 & 0.064 & 0.038 \\
\hline Hamburg (de6) & 0.138 & 0.096 & 0.063 & 0.132 & 0.084 & 0.049 & 0.119 & 0.071 & 0.040 \\
\hline Hessen $(\mathrm{de} 7)$ & 0.141 & 0.100 & 0.067 & 0.142 & 0.095 & 0.062 & 0.117 & 0.070 & 0.039 \\
\hline Mecklenburg-Vorpommern (de8) & 0.107 & 0.072 & 0.044 & 0.109 & 0.068 & 0.038 & 0.098 & 0.058 & 0.032 \\
\hline Niedersachsen (de9) & 0.125 & 0.086 & 0.055 & 0.128 & 0.082 & 0.049 & 0.113 & 0.068 & 0.038 \\
\hline Nordrhein-Westfalen (dea) & 0.132 & 0.091 & 0.059 & 0.135 & 0.087 & 0.052 & 0.119 & 0.072 & 0.041 \\
\hline Sachsen $($ ded $)$ & 0.098 & 0.065 & 0.038 & 0.109 & 0.068 & 0.038 & 0.095 & 0.055 & 0.029 \\
\hline Sachsen-Anhalt (dee) & 0.085 & 0.055 & 0.030 & 0.098 & 0.062 & 0.036 & 0.089 & 0.053 & 0.030 \\
\hline Schleswig-Holstein (def) & 0.112 & 0.075 & 0.045 & 0.133 & 0.088 & 0.056 & 0.111 & 0.066 & 0.037 \\
\hline Thüringen (deg) & 0.094 & 0.063 & 0.039 & 0.101 & 0.064 & 0.038 & 0.087 & 0.051 & 0.028 \\
\hline Rheinland-Pfalz and Saarland (dex) & 0.117 & 0.081 & 0.052 & 0.118 & 0.075 & 0.044 & 0.102 & 0.060 & 0.033 \\
\hline Noroeste (es1) & 0.133 & 0.091 & 0.057 & 0.146 & 0.095 & 0.058 & 0.122 & 0.072 & 0.039 \\
\hline Noreste (es2) & 0.128 & 0.088 & 0.056 & 0.135 & 0.086 & 0.051 & 0.118 & 0.071 & 0.039 \\
\hline Comunidad de Madrid (es3) & 0.139 & 0.098 & 0.065 & 0.144 & 0.094 & 0.058 & 0.125 & 0.076 & 0.044 \\
\hline Centro (es4) & 0.141 & 0.098 & 0.063 & 0.149 & 0.095 & 0.057 & 0.128 & 0.077 & 0.043 \\
\hline Este (es5) & 0.136 & 0.095 & 0.062 & 0.142 & 0.090 & 0.054 & 0.124 & 0.075 & 0.042 \\
\hline Sur (es6) & 0.148 & 0.103 & 0.068 & 0.157 & 0.102 & 0.062 & 0.134 & 0.080 & 0.045 \\
\hline Canarias (es7) & 0.168 & 0.121 & 0.083 & 0.166 & 0.106 & 0.064 & 0.148 & 0.091 & 0.053 \\
\hline Île de France (fr1) & 0.163 & 0.116 & 0.080 & 0.173 & 0.114 & 0.072 & 0.153 & 0.096 & 0.057 \\
\hline
\end{tabular}


Bassin Parisien (fr2)

Nord - Pas-de-Calais (fr3)

\begin{tabular}{lll|ll}
0.128 & 0.087 & 0.054 & 0.139 & 0.088 \\
0.155 & 0.116 & 0.074 & 0.152 & 0.097 \\
0.118 & 0.080 & 0.050 & 0.129 & 0.083 \\
0.119 & 0.082 & 0.053 & 0.120 & 0.076 \\
0.164 & 0.118 & 0.082 & 0.175 & 0.115 \\
0.136 & 0.095 & 0.062 & 0.141 & 0.090 \\
0.148 & 0.103 & 0.068 & 0.153 & 0.098 \\
0.170 & 0.120 & 0.079 & 0.177 & 0.116 \\
0.157 & 0.109 & 0.070 & 0.163 & 0.104 \\
0.130 & 0.089 & 0.056 & 0.141 & 0.091 \\
0.143 & 0.098 & 0.062 & 0.157 & 0.101 \\
0.122 & 0.083 & 0.051 & 0.128 & 0.080 \\
0.111 & 0.074 & 0.045 & 0.125 & 0.080 \\
0.118 & 0.080 & 0.048 & 0.132 & 0.084 \\
0.119 & 0.081 & 0.051 & 0.127 & 0.082 \\
0.112 & 0.075 & 0.045 & 0.120 & 0.075 \\
0.140 & 0.097 & 0.062 & 0.147 & 0.097 \\
0.129 & 0.088 & 0.054 & 0.136 & 0.085 \\
0.137 & 0.093 & 0.059 & 0.145 & 0.092 \\
0.139 & 0.095 & 0.059 & 0.149 & 0.094 \\
0.158 & 0.109 & 0.071 & 0.166 & 0.109 \\
0.144 & 0.097 & 0.058 & 0.166 & 0.108 \\
0.164 & 0.116 & 0.077 & 0.167 & 0.108 \\
0.203 & 0.149 & 0.107 & 0.200 & 0.133 \\
0.167 & 0.121 & 0.085 & 0.162 & 0.106 \\
0.118 & 0.081 & 0.051 & 0.124 & 0.078 \\
0.132 & 0.090 & 0.055 & 0.145 & 0.093 \\
0.131 & 0.090 & 0.057 & 0.136 & 0.087 \\
0.139 & 0.096 & 0.062 & 0.140 & 0.089 \\
0.147 & 0.102 & 0.066 & 0.151 & 0.096 \\
0.139 & 0.096 & 0.062 & 0.139 & 0.088 \\
0.149 & 0.104 & 0.067 & 0.145 & 0.092
\end{tabular}

\begin{tabular}{l|l}
0.052 & 0.123 \\
0.058 & 0.134 \\
0.050 & 0.109 \\
0.045 & 0.106 \\
0.074 & 0.156 \\
0.054 & 0.124 \\
0.059 & 0.132 \\
0.072 & 0.153 \\
0.062 & 0.145 \\
0.055 & 0.122 \\
0.061 & 0.137 \\
0.045 & 0.114 \\
0.047 & 0.111 \\
0.050 & 0.115 \\
0.050 & 0.111 \\
0.042 & 0.109 \\
0.057 & 0.125 \\
0.050 & 0.120 \\
0.055 & 0.127 \\
0.055 & 0.129 \\
0.068 & 0.140 \\
0.066 & 0.143 \\
0.065 & 0.146 \\
0.085 & 0.174 \\
0.065 & 0.143 \\
0.046 & 0.108 \\
0.055 & 0.124 \\
0.051 & 0.117 \\
0.053 & 0.123 \\
0.057 & 0.132 \\
0.051 & 0.125 \\
0.053 & 0.130 \\
&
\end{tabular}

0.074

0.041

Est (fr4)

Ouest (fr5)

Sud-Ouest (fr6)

Centre-Est (fr7)

Méditerranée (fr8)

Voreia Ellada (gr1)

Kentriki Ellada (gr2)

Attiki (gr3)

Nisia Aigaiou, Kriti (gr4)

Nord Ovest (it1)

Lombardia (it2)

Nord Est (it3)

Emilia-Romagna (it4)

Centro (it5)

Lazio (it6)

Abruzzo-Molise (it7)

Campania (it8)

Sud (it9)

Sicilia (ita)

Sardegna (itb)

Continente (pt1)

Açores (pt2)

Madeira (pt3)

North (uk1)

Yorkshire and Humberside (uk2)

East Midlands (uk3)

East Anglia (uk4)

South East (uk5)

South West (uk6)

West Midlands (uk7)

0.104

0.092

0.053

0.130

\subsection{1}

0.045

$0.063 \quad 0.034$

$0.063 \quad 0.035$

$0.099 \quad 0.061$

$0.075 \quad 0.043$

$0.079 \quad 0.044$

$0.094 \quad 0.054$

$0.089 \quad 0.052$

$0.073 \quad 0.041$

$0.083 \quad 0.046$

$0.068 \quad 0.038$

$0.067 \quad 0.038$

$0.069 \quad 0.038$

$0.067 \quad 0.037$

$0.066 \quad 0.037$

$0.074 \quad 0.040$

$0.071 \quad 0.039$

$0.076 \quad 0.043$

$0.077 \quad 0.042$

$0.083-0.046$

$0.086 \quad 0.048$

$0.088 \quad 0.050$

$0.109 \quad 0.065$

$0.088 \quad 0.051$

$0.064 \quad 0.036$

$0.073 \quad 0.040$

$0.070 \quad 0.038$

$0.074 \quad 0.041$

$0.080 \quad 0.045$

$0.076 \quad 0.043$

$0.078 \quad 0.044$ 


\begin{tabular}{l|lll|lll|lll} 
North West (uk8) & 0.131 & 0.090 & 0.056 & 0.142 & 0.091 & 0.054 & 0.123 & 0.074 & 0.041 \\
Wales (uk9) & 0.150 & 0.106 & 0.070 & 0.154 & 0.101 & 0.062 & 0.131 & 0.079 & 0.044 \\
Scotland (uka) & 0.144 & 0.100 & 0.064 & 0.145 & 0.092 & 0.053 & 0.132 & 0.080 & 0.045 \\
\hline Average & 0.134 & 0.093 & 0.060 & 0.141 & 0.090 & 0.054 & 0.124 & 0.074 & 0.042 \\
Standard deviation & 0.020 & 0.016 & 0.013 & 0.019 & 0.013 & 0.009 & 0.017 & 0.011 & 0.007 \\
Minimum & 0.085 & 0.055 & 0.030 & 0.098 & 0.062 & 0.036 & 0.087 & 0.051 & 0.028 \\
Maximum & 0.203 & 0.149 & 0.107 & 0.200 & 0.133 & 0.085 & 0.174 & 0.109 & 0.065 \\
\hline \hline
\end{tabular}

Note: All the values were calculated for 1993. NUTS codes in parentheses. 
1 4 5 6

Table 2: Kendall's rank correlation coefficients between $P^{E G R}$ and various inequality measures.

\begin{tabular}{|c|c|c|c|}
\hline \multirow{3}{*}{$\begin{array}{l}\text { Partition } \\
\text { Inequality indices }\end{array}$} & \multicolumn{3}{|c|}{ Generalized measure of polarization $\left(P^{E G R}\right)$} \\
\hline & Two groups & Three groups & Four groups \\
\hline & $\delta=1 \quad \delta=1.6$ & $\delta=1 \quad \delta=1.6$ & $\delta=1 \quad \delta=1.6$ \\
\hline$G$ & $0.753 * * * 0.665 * * *$ & $0.870 * * * 0.758 * * *$ & $0.878 * * * 0.807 * * *$ \\
\hline$G E(0)$ & $0.622 * * * 0.525 * * *$ & $0.718 * * * 0.627 * * *$ & $0.739 * * * 0.668 * * *$ \\
\hline$G E(1)$ & $0.680 * * * 0.597 * * *$ & $0.792 * * * 0.706 * * *$ & $0.798 * * * 0.745 * * *$ \\
\hline$A(0.5)$ & $0.675 * * * 0.582 * * *$ & $0.790 * * * 0.689 * * *$ & $0.813 * * * 0.746 * * *$ \\
\hline$A(2)$ & $0.215 * * \quad 0.184 * *$ & $0.281 * * * 0.259 * * *$ & $0.266 * * * 0.242 * * *$ \\
\hline
\end{tabular}

Note: * significant at $10 \%, * *$ significant at $5 \%, * * *$ significant at $1 \%$. 
Table 3: Analysis of the variance of polarization measures.

\begin{tabular}{l|cc|cc|cc}
\hline \hline \multicolumn{7}{|c|}{ Generalized measure of polarization $\left(P^{E G R}\right)$} \\
\hline Partition & \multicolumn{2}{|c|}{ Two groups } & \multicolumn{2}{c}{ Three groups } & \multicolumn{2}{c}{ Four groups } \\
\hline Regional category & $\delta=1$ & $\delta=1.6$ & $\delta=1$ & $\delta=1.6$ & $\delta=1$ & $\delta=1.6$ \\
\hline Winning regions $^{(a)}$ & 0.930 & 0.913 & 0.934 & 0.918 & 0.943 & 0.944 \\
Catching-up regions $^{(a)}$ & 0.970 & 0.954 & 0.978 & 0.967 & 0.973 & 0.966 \\
Falling behind regions $^{(a)}$ & 1.036 & 1.053 & 1.033 & 1.050 & 1.040 & 1.047 \\
Losing regions $^{(a)}$ & 1.035 & 1.043 & 1.028 & 1.031 & 1.019 & 1.019 \\
F-test & $3.41^{* *}$ & $3.13 * *$ & $3.39 * *$ & $3.04 * *$ & $2.88^{* *}$ & $2.33^{*}$ \\
\hline \hline
\end{tabular}

Notes: $(1) *$ significant at $10 \%, * *$ significant at $5 \%, * * *$ significant at $1 \% .(2){ }^{(a)}$ Average value of the polarization measure in the category in question. Regional indices were normalized according to the national average. 
Table 4: Regional growth and income polarization in the two-group case.

\begin{tabular}{|c|c|c|c|c|c|c|c|c|}
\hline Independent variable & (1) & (2) & (3) & (4) & (5) & (6) & (7) & $(8)$ \\
\hline Constant & $\begin{array}{c}2.569 * * * \\
(0.524)\end{array}$ & $\begin{array}{c}2.108 * * * \\
(0.381)\end{array}$ & $\begin{array}{c}2.820 * * * \\
(0.527)\end{array}$ & $\begin{array}{c}2.388 * * * \\
(0.408)\end{array}$ & $\begin{array}{c}4.036 * * * \\
(1.243)\end{array}$ & $\begin{array}{l}3.591 * * * \\
(1.245)\end{array}$ & $\begin{array}{c}4.115^{* * *} * \\
(1.260)\end{array}$ & $\begin{array}{c}3.607 * * * \\
(1.247)\end{array}$ \\
\hline$P^{E G R}\left(f, \delta=1, \rho^{*}\right)$ & $\begin{array}{c}-1.569 * * * \\
(0.501)\end{array}$ & & $\begin{array}{c}-1.302 * * * \\
(0.398)\end{array}$ & & $\begin{array}{c}-1.301 * * * \\
(0.407)\end{array}$ & & $\begin{array}{c}-1.527 * * * \\
(0.426)\end{array}$ & \\
\hline$P^{E G R}\left(f, \delta=1.6, \rho^{*}\right)$ & & $\begin{array}{c}-1.108 * * * \\
(0.358)\end{array}$ & & $\begin{array}{c}-0.886^{* * *} \\
(0.285)\end{array}$ & & $\begin{array}{c}-0.825 * * * \\
(0.302)\end{array}$ & & $\begin{array}{c}-0.998 * * * \\
(0.308)\end{array}$ \\
\hline Per capita GDP & & & $\begin{array}{c}-0.518 * * * \\
(0.178)\end{array}$ & $\begin{array}{c}-0.502 * * * \\
(0.176)\end{array}$ & $\begin{array}{c}-0.574 * \\
(0.300)\end{array}$ & $\begin{array}{c}-0.600 * \\
(0.309)\end{array}$ & & \\
\hline Emp. share in agriculture & & & & & $\begin{array}{l}-0.191 \\
(0.139)\end{array}$ & $\begin{array}{l}-0.211 \\
(0.143)\end{array}$ & $\begin{array}{l}-0.117 \\
(0.136)\end{array}$ & $\begin{array}{l}-0.135 \\
(0.139)\end{array}$ \\
\hline Emp. share in manufacturing & & & & & $\begin{array}{c}-0.698 * * * \\
(0.229)\end{array}$ & $\begin{array}{c}-0.676^{* * *} \\
(0.239)\end{array}$ & $\begin{array}{c}-0.697 * * * \\
(0.232)\end{array}$ & $\begin{array}{c}-0.671 * * * \\
(0.243)\end{array}$ \\
\hline Emp. share in market services & & & & & $\begin{array}{c}0.349 \\
(0.590)\end{array}$ & $\begin{array}{c}0.348 \\
(0.616)\end{array}$ & $\begin{array}{l}-0.178 \\
(0.667)\end{array}$ & $\begin{array}{l}-0.196 \\
(0.696)\end{array}$ \\
\hline Emp. share in non-market services & & & & & $\begin{array}{c}-1.327 * * * \\
(0.456)\end{array}$ & $\begin{array}{c}-1.352 * * * \\
(0.464)\end{array}$ & $\begin{array}{c}-1.097 * * \\
(0.434)\end{array}$ & $\begin{array}{c}-1.112^{* *} \\
(0.440)\end{array}$ \\
\hline Pop. share with secondary education & & & & & $\begin{array}{c}0.301 \\
(0.297)\end{array}$ & $\begin{array}{c}0.320 \\
(0.309)\end{array}$ & $\begin{array}{c}0.238 \\
(0.292)\end{array}$ & $\begin{array}{c}0.255 \\
(0.302)\end{array}$ \\
\hline Pop. share with tertiary education & & & & & $0.415 * * *$ & $0.420 * * *$ & $0.459 * * *$ & $0.466 * * *$ \\
\hline
\end{tabular}




\begin{tabular}{|c|c|c|c|c|c|c|c|c|}
\hline \multirow{3}{*}{ Population density } & & & & & $(0.133)$ & $(0.138)$ & $(0.135)$ & $(0.141)$ \\
\hline & & & & & -0.132 & -0.134 & -0.147 & -0.149 \\
\hline & & & & & $(0.116)$ & $(0.117)$ & $(0.109)$ & $(0.110)$ \\
\hline \multirow[t]{2}{*}{ Market potential } & & & & & 0.121 & 0.117 & -0.050 & -0.067 \\
\hline & & & & & $(0.301)$ & $(0.307)$ & $(0.306)$ & $(0.312)$ \\
\hline F-test & $9.79 * * *$ & $9.58 * * *$ & $6.31 * * *$ & $6.23 * * *$ & $5.23 * * *$ & $5.08^{* * *}$ & $4.97 * * *$ & $4.85^{* * *}$ \\
\hline Test for spatial dependence & 0.768 & 0.747 & 0.629 & 0.622 & 10.997 & 10.630 & 8.160 & 7.861 \\
\hline Condition number & 18.71 & 13.42 & 22.77 & 16.36 & 94.40 & 92.41 & 89.14 & 87.53 \\
\hline R-squared & 0.183 & 0.178 & 0.289 & 0.276 & 0.538 & 0.520 & 0.507 & 0.487 \\
\hline
\end{tabular}

Notes: (1) The dependent variable is in all cases the annual growth rate of the sample regions during the study period. (2) All the variables were normalized according to the national average. (3) Standard errors in parentheses. The reported standard errors are based on the heteroskedasticity consistent estimator of the covariance matrix of the regression coefficients proposed by White (1980). (4) * significant at 10\%, ** significant at 5\%, $* * *$ significant at $1 \%$. 
Table 5: Regional growth and income polarization in the three-group case.

\begin{tabular}{|c|c|c|c|c|c|c|c|c|}
\hline Independent variable & (1) & (2) & (3) & (4) & (5) & (6) & (7) & (8) \\
\hline Constant & $\begin{array}{c}2.712 * * * \\
(0.575)\end{array}$ & $\begin{array}{c}2.238 * * * \\
(0.410)\end{array}$ & $\begin{array}{c}2.990 * * * \\
(0.574)\end{array}$ & $\begin{array}{c}2.563 * * * \\
(0.437)\end{array}$ & $\begin{array}{c}4.196 * * * \\
(1.284)\end{array}$ & $\begin{array}{c}3.565 * * * \\
(1.277)\end{array}$ & $\begin{array}{c}4.303 * * * \\
(1.310)\end{array}$ & $\begin{array}{c}3.591 * * * \\
(1.281)\end{array}$ \\
\hline$P^{E G R}\left(f, \delta=1, \rho^{*}\right)$ & $\begin{array}{c}-1.712 * * * \\
(0.554)\end{array}$ & & $\begin{array}{c}-1.451 * * * \\
(0.445)\end{array}$ & & $\begin{array}{c}-1.512 * * * \\
(0.411)\end{array}$ & & $\begin{array}{c}-1.763 * * * \\
(0.435)\end{array}$ & \\
\hline$P^{E G R}\left(f, \delta=1.6, \rho^{*}\right)$ & 5 & $\begin{array}{c}-1.238 * * * \\
(0.387)\end{array}$ & & $\begin{array}{c}-1.032 * * * \\
(0.309)\end{array}$ & & $\begin{array}{c}-0.961 * * * \\
(0.282)\end{array}$ & & $\begin{array}{c}-1.161 * * * * \\
(0.291)\end{array}$ \\
\hline Per capita GDP & & & $\begin{array}{c}-0.539 * * * \\
(0.183)\end{array}$ & $\begin{array}{c}-0.531 * * * \\
(0.179)\end{array}$ & $\begin{array}{l}-0.526^{*} \\
(0.280)\end{array}$ & $\begin{array}{l}-0.510^{*} \\
(0.289)\end{array}$ & & \\
\hline Emp. share in agriculture & & & & & $\begin{array}{l}-0.180 \\
(0.135)\end{array}$ & $\begin{array}{l}-0.186 \\
(0.137)\end{array}$ & $\begin{array}{l}-0.112 \\
(0.132)\end{array}$ & $\begin{array}{l}-0.117 \\
(0.132)\end{array}$ \\
\hline Emp. share in manufacturing & & & & & $\begin{array}{c}-0.718 * * * \\
(0.230)\end{array}$ & $\begin{array}{c}-0.680^{* * *} \\
(0.242)\end{array}$ & $\begin{array}{c}-0.720 * * * \\
(0.228)\end{array}$ & $\begin{array}{c}-0.677 * * * \\
(0.242)\end{array}$ \\
\hline Emp. share in market services & & & & & $\begin{array}{c}0.270 \\
(0.564)\end{array}$ & $\begin{array}{c}0.197 \\
(0.586)\end{array}$ & $\begin{array}{l}-0.216 \\
(0.625)\end{array}$ & $\begin{array}{l}-0.262 \\
(0.639)\end{array}$ \\
\hline Emp. share in non-market services & & & & & $\begin{array}{c}-1.262 * * * \\
(0.457)\end{array}$ & $\begin{array}{c}-1.193 * * \\
(0.471)\end{array}$ & $\begin{array}{c}-1.043 * * \\
(0.439)\end{array}$ & $\begin{array}{c}-0.963 * * \\
(0.449)\end{array}$ \\
\hline Pop. share with secondary education & & & & & 0.278 & 0.276 & 0.217 & 0.210 \\
\hline
\end{tabular}




\begin{tabular}{|c|c|c|c|c|c|c|c|c|}
\hline \multirow{3}{*}{ Pop. share with tertiary education } & & & & & $(0.304)$ & $(0.318)$ & $(0.298)$ & $(0.312)$ \\
\hline & & & & & $0.441 * * *$ & $0.455^{* * *}$ & $0.485^{* * *}$ & $0.497 * * *$ \\
\hline & & & & & $(0.128)$ & $(0.131)$ & $(0.129)$ & $(0.130)$ \\
\hline \multirow[t]{2}{*}{ Population density } & & & & & -0.138 & -0.143 & -0.152 & -0.157 \\
\hline & & & & & $(0.118)$ & $(0.119)$ & $(0.111)$ & $(0.113)$ \\
\hline \multirow[t]{2}{*}{ Market potential } & & & & & 0.152 & 0.180 & 0.001 & 0.038 \\
\hline & & & & & $(0.306)$ & $(0.317)$ & $(0.312)$ & $(0.320)$ \\
\hline F-test & $9.54 * * *$ & $10.23 * * *$ & $6.35^{* * * *}$ & $6.79 * * *$ & $5.96 * * *$ & $5.83 * * *$ & $5.71 * * *$ & $5.69 * * *$ \\
\hline Test for spatial dependence & 0.739 & 0.740 & 0.605 & 0.606 & 12.018 & 11.547 & 9.277 & 9.171 \\
\hline Condition number & 20.97 & 15.24 & 25.52 & 18.60 & 95.40 & 92.35 & 89.84 & 87.42 \\
\hline R-squared & 0.173 & 0.172 & 0.290 & 0.284 & 0.547 & 0.528 & 0.522 & 0.505 \\
\hline
\end{tabular}

Notes: (1) The dependent variable is in all cases the annual growth rate of the sample regions during the study period. (2) All the variables were normalized according to the national average. (3) Standard errors in parentheses. The reported standard errors are based on the heteroskedasticity consistent estimator of the covariance matrix of the regression coefficients proposed by White (1980). (4) * significant at 10\%, ** significant at $5 \%, * * *$ significant at $1 \%$. 
Table 6: Regional growth and income polarization in the four-group case.

\begin{tabular}{|c|c|c|c|c|c|c|c|c|}
\hline Independent variable & (1) & (2) & (3) & (4) & (5) & (6) & (7) & (8) \\
\hline Constant & $\begin{array}{c}2.470 * * * \\
(0.537)\end{array}$ & $\begin{array}{c}2.113 * * * \\
(0.502)\end{array}$ & $\begin{array}{c}2.576 * * * \\
(0.542)\end{array}$ & $\begin{array}{c}2.277 * * * \\
(0.483)\end{array}$ & $\begin{array}{c}4.335 * * * \\
(1.399)\end{array}$ & $\begin{array}{c}3.815 * * \\
(1.456)\end{array}$ & $\begin{array}{c}4.537 * * * \\
(1.432)\end{array}$ & $\begin{array}{c}4.007 * * * \\
(1.482)\end{array}$ \\
\hline$P^{E G R}\left(f, \delta=1, \rho^{*}\right)$ & $\begin{array}{c}-1.470 * * * \\
(0.514)\end{array}$ & & $\begin{array}{c}-1.068 * * \\
(0.424)\end{array}$ & & $\begin{array}{c}-1.336 * * * \\
(0.464)\end{array}$ & & $\begin{array}{c}-1.618 * * * \\
(0.451)\end{array}$ & \\
\hline$P^{E G R}\left(f, \delta=1.6, \rho^{*}\right)$ & & $\begin{array}{c}-1.113^{* *} \\
(0.478)\end{array}$ & & $\begin{array}{l}-0.755^{*} \\
(0.385)\end{array}$ & & $\begin{array}{l}-0.776^{*} \\
(0.445)\end{array}$ & & $\begin{array}{c}-1.066 * * \\
(0.443)\end{array}$ \\
\hline Per capita GDP & & & $\begin{array}{c}-0.508 * * * \\
(0.186)\end{array}$ & $\begin{array}{c}-0.522 * * * \\
(0.186)\end{array}$ & $\begin{array}{l}-0.448 \\
(0.293)\end{array}$ & $\begin{array}{c}-0.567^{*} \\
(0.283)\end{array}$ & & \\
\hline Emp. share in agriculture & & & & & $\begin{array}{l}-0.233 * \\
(0.138)\end{array}$ & $\begin{array}{l}-0.250 * \\
(0.137)\end{array}$ & $\begin{array}{l}-0.181 \\
(0.134)\end{array}$ & $\begin{array}{l}-0.182 \\
(0.136)\end{array}$ \\
\hline Emp. share in manufacturing & & & & & $\begin{array}{c}-0.815^{* * *} \\
(0.251)\end{array}$ & $\begin{array}{c}-0.750 * * * \\
(0.259)\end{array}$ & $\begin{array}{c}-0.841 * * * \\
(0.244)\end{array}$ & $\begin{array}{c}-0.771 * * * \\
(0.256)\end{array}$ \\
\hline Emp. share in market services & & & & & $\begin{array}{c}0.037 \\
(0.573)\end{array}$ & $\begin{array}{r}0.083 \\
(0.609)\end{array}$ & $\begin{array}{l}-0.374 \\
(0.634)\end{array}$ & $\begin{array}{l}-0.433 \\
(0.650)\end{array}$ \\
\hline Emp. share in non-market services & & & & & $\begin{array}{c}-1.368 * * * \\
(0.482)\end{array}$ & $\begin{array}{c}-1.431 * * * \\
(0.488)\end{array}$ & $\begin{array}{c}-1.204 * * \\
(0.460)\end{array}$ & $\begin{array}{c}-1.233 * * \\
(0.471)\end{array}$ \\
\hline Pop. share with secondary education & & & & & $\begin{array}{c}0.334 \\
(0.306)\end{array}$ & $\begin{array}{c}0.384 \\
(0.328)\end{array}$ & $\begin{array}{c}0.286 \\
(0.297)\end{array}$ & $\begin{array}{c}0.331 \\
(0.315)\end{array}$ \\
\hline Pop. share with tertiary education & & & & & $0.459 * * *$ & $0.453 * * *$ & $0.493 * * *$ & $0.492 * * *$ \\
\hline
\end{tabular}




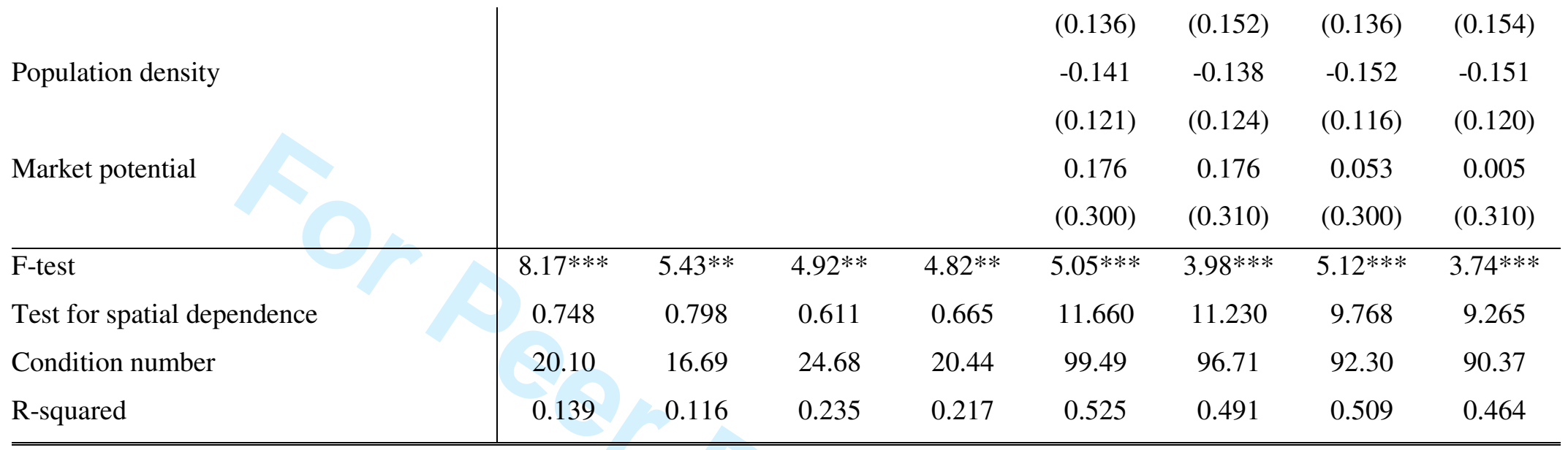

Notes: (1) The dependent variable is in all cases the annual growth rate of the sample regions during the study period. (2) All the variables were normalized according to the national average. (3) Standard errors in parentheses. The reported standard errors are based on the heteroskedasticity consistent estimator of the covariance matrix of the regression coefficients proposed by White (1980). (4) * significant at 10\%, ** significant at 5\%, *** significant at $1 \%$. 
Table 7: The relationship between regional growth and the two components of $P^{E G R}$ : polarization of the simplified representation of the original distribution and within-group dispersion.

\begin{tabular}{|c|c|c|c|c|}
\hline \multicolumn{5}{|c|}{ Two-group partition } \\
\hline$P^{E R}\left(\delta=1, \rho^{*}\right)$ & $P^{E R}\left(\delta=1.6, \rho^{*}\right)$ & $\varepsilon\left(f, \rho^{*}\right)$ & R-squared & Controls \\
\hline \multirow{5}{*}{$\begin{array}{c}-1.655^{* * *} \\
(0.583)\end{array}$} & & & 0.150 & $\mathrm{NO}$ \\
\hline & & & & \\
\hline & $-1.458 * * *$ & & 0.137 & NO \\
\hline & & $-1.169^{*}$ & 0.064 & NO \\
\hline & & $(0.585)$ & & \\
\hline \multirow{5}{*}{$\begin{array}{c}-1.551 * * * \\
(0.450)\end{array}$} & & & 0.543 & YES \\
\hline & $-1.370 * * *$ & & 0.535 & YES \\
\hline & $(0.425)$ & & & \\
\hline & & $-1.353 * *$ & 0.520 & YES \\
\hline & & $(0.514)$ & & \\
\hline
\end{tabular}

Three-group partition

\begin{tabular}{|c|c|c|c|c|}
\hline$P^{E R}\left(\delta=1, \rho^{*}\right)$ & $P^{E R}\left(\delta=1.6, \rho^{*}\right)$ & $\varepsilon\left(f, \rho^{*}\right)$ & R-squared & Controls \\
\hline \multirow{6}{*}{$\begin{array}{c}-1.659 * * * \\
(0.586)\end{array}$} & & & 0.147 & $\mathrm{NO}$ \\
\hline & & & & \\
\hline & $-1.396 * * *$ & & 0.138 & NO \\
\hline & $(0.504)$ & & & \\
\hline & & $-1.026^{*}$ & 0.053 & NO \\
\hline & & $(0.611)$ & & \\
\hline \multirow{5}{*}{$\begin{array}{c}-1.541 * * * \\
(0.453)\end{array}$} & \multirow{5}{*}{$\begin{array}{c}-1.242 * * * \\
(0.395)\end{array}$} & & 0.542 & YES \\
\hline & & & 0530 & YES \\
\hline & & & & \\
\hline & & $1.166^{* * *}$ & 0.521 & YES \\
\hline & & $(0.521)$ & & \\
\hline \multicolumn{5}{|c|}{ Four-group partition } \\
\hline$P^{E R}\left(\delta=1, \rho^{*}\right)$ & $P^{E R}\left(\delta=1.6, \rho^{*}\right)$ & $\varepsilon\left(f, \rho^{*}\right)$ & R-squared & Controls \\
\hline$-1.526 * * *$ & & & 0.135 & NO \\
\hline \multicolumn{5}{|l|}{$(0.542)$} \\
\hline & $-1.334 * *$ & & 0.115 & NO \\
\hline
\end{tabular}


$(0.555)$

$\begin{array}{ccc}-1.415^{* *} & 0.084 & \text { NO } \\ (0.684) & & \\ & 0.530 & \text { YES }\end{array}$

$-1.421^{* * *}$

$0.530 \quad$ YES

$(0.471)$

$-1.110^{* *}$

0.510

YES

(0.482)

$-1.583 * * *$

0.540

YES

$(0.468)$

\begin{abstract}
Notes: (1) The dependent variable is in all cases the annual growth rate of the sample regions during the study period. (2) All the variables were normalized according to the national average. (3) Standard errors in parentheses. The reported standard errors are based on the heteroskedasticity consistent estimator of the covariance matrix of the regression coefficients proposed by White (1980). (4) * significant at $10 \%$, ** significant at $5 \%$, *** significant at $1 \%$.(5) Control variables include initial per capita GDP, employment share in agriculture, manufacturing, market and non-market services, population share with secondary and tertiary education, population density and market potential.
\end{abstract}


Table A1: Decomposition of the $P^{E G R}$ index.

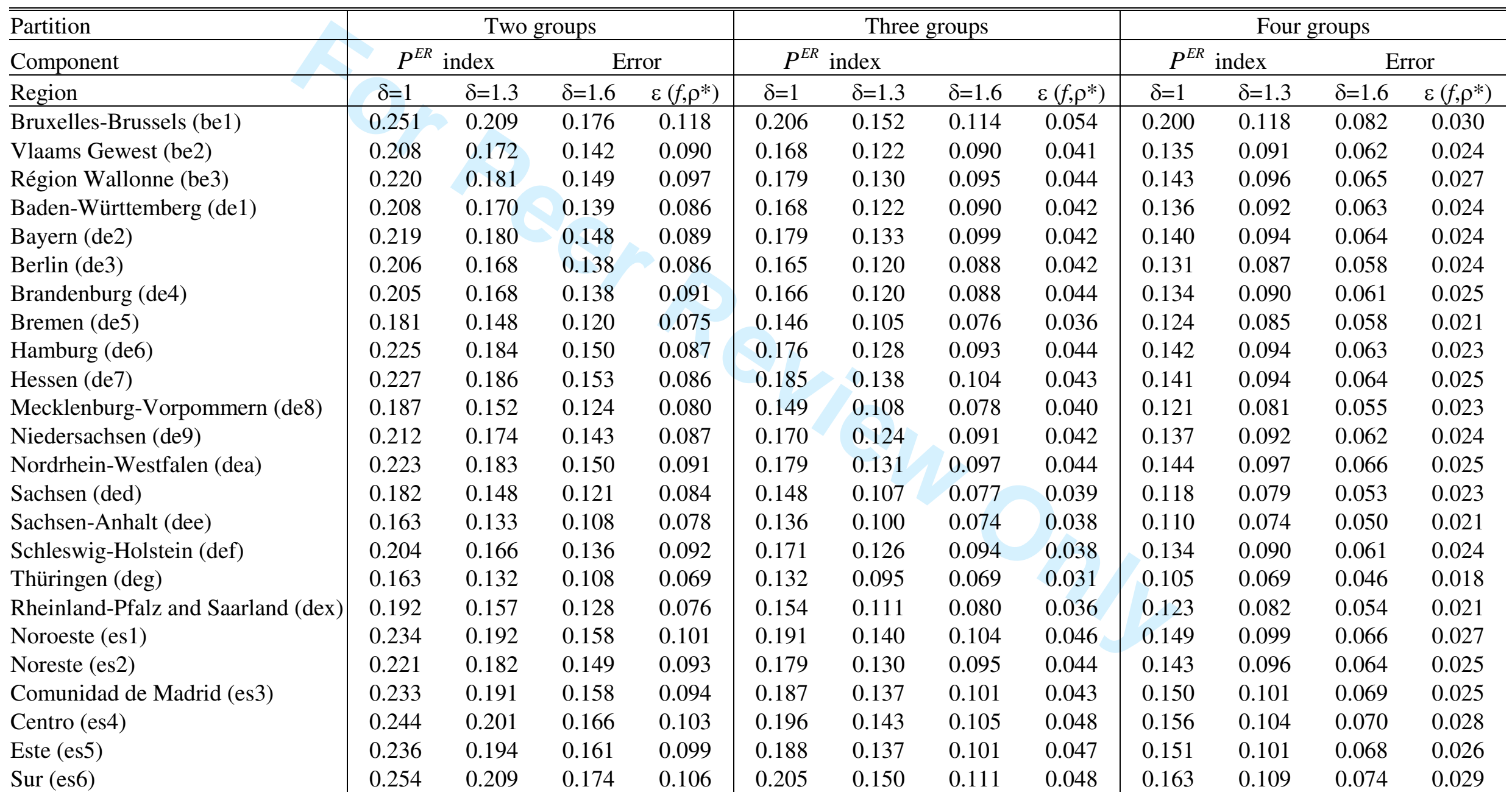


Canarias (es7)

Île de France (fr1)

Bassin Parisien (fr2)

Nord - Pas-de-Calais (fr3)

Est (fr4)

Ouest (fr5)

Sud-Ouest (fr6)

Centre-Est (fr7)

Méditerranée (fr8)

Voreia Ellada (gr1)

Kentriki Ellada (gr2)

Attiki (gr3)

Nisia Aigaiou, Kriti (gr4)

Nord Ovest (it1)

Lombardia (it2)

Nord Est (it3)

Emilia-Romagna (it4)

Centro (it5)

Lazio (it6)

Abruzzo-Molise (it7)

Campania (it8)

Sud (it9)

Sicilia (ita)

Sardegna (itb)

Continente (pt1)

Açores (pt2)

Madeira (pt3)

North (uk1)

Yorkshire and Humberside (uk2)

East Midlands (uk3)

East Anglia (uk4)

\begin{tabular}{|c|c|c|c|c|c|c|c|c|c|c|c|}
\hline 0.281 & 0.234 & 0.196 & 0.113 & 0.220 & 0.160 & 0.117 & 0.054 & 0.178 & 0.121 & 0.083 & 0.030 \\
\hline 0.286 & 0.240 & 0.203 & 0.124 & 0.230 & 0.171 & 0.129 & 0.057 & 0.185 & 0.128 & 0.089 & 0.032 \\
\hline 0.231 & 0.190 & 0.157 & 0.103 & 0.187 & 0.137 & 0.101 & 0.049 & 0.151 & 0.102 & 0.070 & 0.028 \\
\hline 0.257 & 0.218 & 0.176 & 0.102 & 0.203 & 0.148 & 0.109 & 0.051 & 0.163 & 0.110 & 0.075 & 0.029 \\
\hline 0.210 & 0.172 & 0.142 & 0.092 & 0.171 & 0.124 & 0.091 & 0.042 & 0.134 & 0.089 & 0.059 & 0.025 \\
\hline 0.200 & 0.164 & 0.134 & 0.081 & 0.159 & 0.115 & 0.084 & 0.039 & 0.128 & 0.085 & 0.057 & 0.022 \\
\hline 0.288 & 0.242 & 0.206 & 0.124 & 0.235 & 0.175 & 0.134 & 0.060 & 0.188 & 0.131 & 0.092 & 0.031 \\
\hline 0.231 & 0.189 & 0.156 & 0.094 & 0.185 & 0.134 & 0.098 & 0.044 & 0.150 & 0.101 & 0.069 & 0.026 \\
\hline 0.252 & 0.208 & 0.172 & 0.104 & 0.202 & 0.147 & 0.108 & 0.049 & 0.161 & 0.108 & 0.073 & 0.029 \\
\hline 0.289 & 0.239 & 0.198 & 0.119 & 0.233 & 0.171 & 0.127 & 0.056 & 0.185 & 0.125 & 0.086 & 0.032 \\
\hline 0.267 & 0.219 & 0.181 & 0.110 & 0.213 & 0.154 & 0.112 & 0.050 & 0.174 & 0.118 & 0.081 & 0.029 \\
\hline 0.231 & 0.190 & 0.156 & 0.101 & 0.188 & 0.137 & 0.101 & 0.047 & 0.150 & 0.101 & 0.068 & 0.028 \\
\hline 0.256 & 0.210 & 0.174 & 0.112 & 0.208 & 0.152 & 0.112 & 0.051 & 0.166 & 0.111 & 0.075 & 0.029 \\
\hline 0.216 & 0.177 & 0.145 & 0.094 & 0.173 & 0.125 & 0.091 & 0.045 & 0.140 & 0.094 & 0.063 & 0.025 \\
\hline 0.205 & 0.168 & 0.139 & 0.094 & 0.168 & 0.122 & 0.090 & 0.043 & 0.135 & 0.091 & 0.062 & 0.024 \\
\hline 0.215 & 0.176 & 0.145 & 0.097 & 0.176 & 0.128 & 0.094 & 0.044 & 0.140 & 0.094 & 0.063 & 0.025 \\
\hline 0.207 & 0.169 & 0.138 & 0.087 & 0.169 & 0.124 & 0.092 & 0.042 & 0.134 & 0.090 & 0.061 & 0.024 \\
\hline 0.203 & 0.166 & 0.136 & 0.092 & 0.164 & 0.119 & 0.086 & 0.044 & 0.134 & 0.091 & 0.062 & 0.025 \\
\hline 0.240 & 0.197 & 0.162 & 0.100 & 0.194 & 0.143 & 0.104 & 0.047 & 0.152 & 0.101 & 0.067 & 0.027 \\
\hline 0.224 & 0.183 & 0.150 & 0.095 & 0.180 & 0.130 & 0.094 & 0.045 & 0.145 & 0.096 & 0.064 & 0.025 \\
\hline 0.238 & 0.195 & 0.161 & 0.102 & 0.192 & 0.139 & 0.102 & 0.047 & 0.155 & 0.104 & 0.070 & 0.027 \\
\hline 0.247 & 0.202 & 0.167 & 0.108 & 0.199 & 0.145 & 0.105 & 0.051 & 0.159 & 0.106 & 0.072 & 0.030 \\
\hline 0.270 & 0.222 & 0.183 & 0.112 & 0.220 & 0.162 & 0.121 & 0.053 & 0.170 & 0.113 & 0.076 & 0.031 \\
\hline 0.263 & 0.216 & 0.177 & 0.119 & 0.218 & 0.160 & 0.119 & 0.053 & 0.173 & 0.116 & 0.078 & 0.030 \\
\hline 0.277 & 0.229 & 0.190 & 0.113 & 0.220 & 0.161 & 0.118 & 0.053 & 0.176 & 0.119 & 0.081 & 0.031 \\
\hline 0.326 & 0.272 & 0.229 & 0.123 & 0.257 & 0.190 & 0.141 & 0.057 & 0.207 & 0.141 & 0.098 & 0.033 \\
\hline 0.274 & 0.228 & 0.191 & 0.107 & 0.215 & 0.158 & 0.118 & 0.053 & 0.172 & 0.117 & 0.080 & 0.029 \\
\hline 0.205 & 0.168 & 0.138 & 0.087 & 0.165 & 0.120 & 0.087 & 0.041 & 0.132 & 0.088 & 0.060 & 0.024 \\
\hline 0.233 & 0.191 & 0.157 & 0.101 & 0.190 & 0.138 & 0.101 & 0.045 & 0.150 & 0.099 & 0.066 & 0.026 \\
\hline 0.224 & 0.183 & 0.150 & 0.094 & 0.180 & 0.130 & 0.095 & 0.044 & 0.144 & 0.096 & 0.064 & 0.026 \\
\hline 0.231 & 0.189 & 0.154 & 0.092 & 0.184 & 0.133 & 0.097 & 0.044 & 0.147 & 0.098 & 0.065 & 0.024 \\
\hline
\end{tabular}

http://mc.manuscriptcentral.com/cres Email: regional.studies@fm.ru.nl 


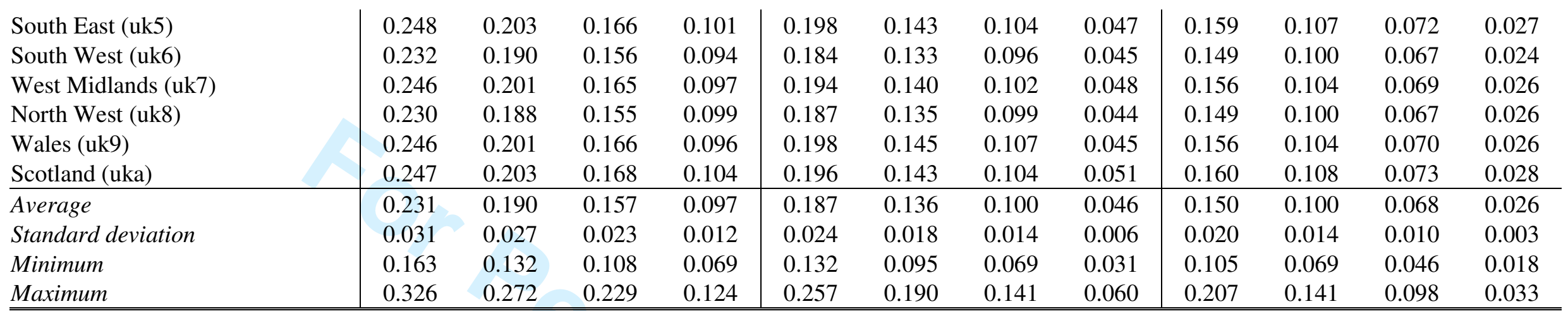

Note: All the values were calculated for 1993. NUTS codes in parentheses. 
Table A2: Kendall's rank correlation coefficients between the $P^{E G R}$ indices obtained with different values of the polarization sensitivity parameter.

\begin{tabular}{l|c|c|c}
\hline \hline Partition & Two groups & Three groups & Four groups \\
\hline$\delta=1, \delta=1.3$ & $0.947 * * *$ & $0.938^{* * *}$ & $0.938 * * *$ \\
$\delta=1, \delta=1.6$ & $0.898^{* * *}$ & $0.867 * * *$ & $0.869 * * *$ \\
$\delta=1.3, \delta=1.6$ & $0.942 * * *$ & $0.925 * * *$ & $0.914 * * *$ \\
\hline \hline
\end{tabular}

Note: * significant at 10\%, $* *$ significant at $5 \%, * * *$ significant at $1 \%$. 


\title{
Notes
}

\begin{abstract}
${ }^{i}$ NUTS is the French acronym for "Nomenclature of Territorial Units for Statistics", a hierarchical classification of subnational spatial units established by Eurostat. In this classification NUTS-0 corresponds to country level and increasing numbers indicate increasing levels of subnational disaggregation.

${ }^{\mathrm{ii}}$ See the Appendix for further details on the regions and data employed in the article.

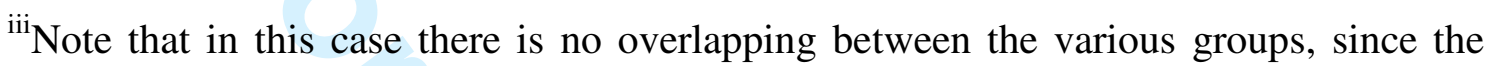
decomposition of the Gini index into between-group and within-group inequality is exact (PYATT, 1976).
\end{abstract}

${ }^{\text {iv }}$ This choice is due to the fact that, as mentioned above, the formulation of $P^{E R}$ is similar to that of the Gini index. The second term in expression (3) is in fact the difference between two Gini indices. It is therefore reasonable to select in empirical analyses a value of $\delta$ equal to the unit (DURO, 2005).

${ }^{\mathrm{v}}$ It is worth mentioning that Rheinland-Pfalz and Saarland are considered as a single region in the ECHP. In turn, lack of regional data in the ECHP has obliged us to exclude from our study the French overseas departments and Northern Ireland. 